Article

\title{
Structural and Functional Dynamics of Staphylococcus aureus Biofilms and Biofilm Matrix Proteins on Different Clinical Materials
}

\author{
Anna K. Hiltunen ${ }^{1}$, Kirsi Savijoki ${ }^{1}{ }^{\circledR}$, Tuula A. Nyman ${ }^{2}{ }^{\circledR}$, Ilkka Miettinen ${ }^{1}$, \\ Petri Ihalainen ${ }^{3,+} \mathbb{D}$, Jouko Peltonen ${ }^{3}$ and Adyary Fallarero ${ }^{1, *}$ \\ 1 Pharmaceutical Design and Discovery (PharmDD) Group, Pharmaceutical Biology, \\ Division of Pharmaceutical Biosciences, Faculty of Pharmacy, University of Helsinki, Viikinkaari 5, \\ 00014 Helsinki, Finland; anna.k.hiltunen@helsinki.fi (A.K.H.); kirsi.savijoki@helsinki.fi (K.S.); \\ ilkka.miettinen@helsinki.fi (I.M.) \\ 2 Department of Immunology, Institute of Clinical Medicine, University of Oslo and Rikshospitalet Oslo, \\ 0372 Oslo, Norway; t.a.nyman@medisin.uio.no \\ 3 Laboratory of Physical Chemistry, Åbo Akademi University, Porthaninkatu 3-5, 20500 Turku, Finland; \\ petri.ihalainen@metgen.com (P.I.); jouko.peltonen@abo.fi (J.P.) \\ * Correspondence: adyary.fallarero@helsinki.fi; Tel.: +35-84-4283-4933 \\ † Present address: MetGen Oy, Rakentajantie 26, 20780 Kaarina, Finland.
}

Received: 25 October 2019; Accepted: 18 November 2019; Published: 20 November 2019

\begin{abstract}
Medical device-associated staphylococcal infections are a common and challenging problem. However, detailed knowledge of staphylococcal biofilm dynamics on clinically relevant surfaces is still limited. In the present study, biofilm formation of the Staphylococcus aureus ATCC 25923 strain was studied on clinically relevant materials-borosilicate glass, plexiglass, hydroxyapatite, titanium and polystyrene-at 18, 42 and $66 \mathrm{~h}$. Materials with the highest surface roughness and porosity (hydroxyapatite and plexiglass) did not promote biofilm formation as efficiently as some other selected materials. Matrix-associated poly- $N$-acetyl- $\beta-(1-6)$-glucosamine (PNAG) was considered important in young $(18 \mathrm{~h})$ biofilms, whereas proteins appeared to play a more important role at later stages of biofilm development. A total of 460 proteins were identified from biofilm matrices formed on the indicated materials and time points-from which, 66 proteins were proposed to form the core surfaceome. At $18 \mathrm{~h}$, the appearance of several r-proteins and glycolytic adhesive moonlighters, possibly via an autolysin (AtlA)-mediated release, was demonstrated in all materials, whereas classical surface adhesins, resistance- and virulence-associated proteins displayed greater variation in their abundances depending on the used material. Hydroxyapatite-associated biofilms were more susceptible to antibiotics than biofilms formed on titanium, but no clear correlation between the tolerance and biofilm age was observed. Thus, other factors, possibly the adhesive moonlighters, could have contributed to the observed chemotolerant phenotype. In addition, a protein-dependent matrix network was observed to be already well-established at the $18 \mathrm{~h}$ time point. To the best of our knowledge, this is among the first studies shedding light into matrix-associated surfaceomes of S. aureus biofilms grown on different clinically relevant materials and at different time points.
\end{abstract}

Keywords: Staphylococcus aureus; biofilm matrix; clinical material; exopolysaccharide; proteins; surfaceome

\section{Introduction}

Implanted medical devices have been consistently shown to improve the quality of life of patients suffering from critical conditions such as the destruction of joints [1]. Increasing life span and evolving medical sciences have accelerated the use of such devices. However, paradoxically, this trend has 
also increased the propensity to device-associated infections. In joint replacements, infection rates have been estimated to be approximately $1.7 \%$ in hip, $2 \%$ in knee and $9 \%$ in ankle prostheses [2]. In addition, 5-10\% of inserted internal fixation devices can typically become infected [3]. Elderly, obese, malnourished, diabetic and rheumatic patients and near-surface body inserts with poor soft tissue coverage are most vulnerable to such infections. Medical device-associated infections are common complications of implantation surgery caused by material-colonizing microbial communities, also known as biofilms [1].

Staphylococcal spp. biofilms are one of the frequent causes of certain medical device-associated infections, such as infections related to intravenous catheters [4,5], cardiac pacemakers [6] and mammary implants [7,8]. In prosthetic joint infections, especially Staphylococcus aureus is largely responsible for early post-interventional infection types [9]. Biofilms refer to complex communities of bacteria, which can be attached to a surface or form aggregates without attachment to any surface. Biofilms differ from free-floating cells by slow growth and tolerance to antibiotics and immune cells of the host [10-13]. Freely floating bacteria are responsible for colonizing new niches, while the biofilm lifestyle, preferred by most of the bacteria, serves as a survival strategy against external threats [14]. Increased adaptation, adherence and antibiotic tolerance are characteristic features of the bacterial biofilm. These features are to a great extent connected to a slimy structure surrounding the bacterial cell community known as the biofilm matrix, which forms approximately $90 \%$ of the biofilm dry mass and it is comprised of hydrated extracellular polymeric components (EPS), such as exopolysaccharides, proteins, lipids and nucleic acids [15]. The biofilm matrix is likely to change as biofilms develop over time, and it is also different between biofilms formed on different surfaces. Those changes in the biofilm matrix are likely crucial for understanding antibiotic tolerance and designing better anti-biofilm therapies. However, the dynamics of such changes have been poorly investigated, thus far.

Bacteria may colonize indwelling medical devices during implantation or at later stages by hematogenous seeding. After implantation, medical devices are promptly coated by host proteins, involving fibrinogen, fibronectin and fibrin, which can facilitate adhesion of bacteria like Staphylococcus aureus that express receptors for binding these plasma proteins [16,17]. The implant-induced changes in the host, such as reduced blood flow and impaired activity of lymphocytic and phagocytic cells, are other factors that can also promote the biofilm formation on medical devices [1]. Besides, some substrate materials such as polymethyl methacrylate, acrylic glass (PMMA) can intrinsically contribute to biofilm formation by hampering the complement and reducing leukocytic activity. Notably, phagocytic cells often focus on degrading the medical device itself, not the bacteria. Strategies to cope with such infections have involved systemically administered antibiotics [18]. However, achieving an adequate concentration of the antibiotic at the biofilm infection site is difficult due to reduced local tissue perfusion and compromised vasculature $[19,20]$. Thus, removal of the device and debridement of the necrotic tissue is often required in conjunction with the insertion of a new medical device, which often leads to revision surgeries and prolonged hospitalization periods with a high risk for re-infections $[3,21]$. A systemic antibiotic prophylaxis during the time of the surgery together with the coating of the inserted devices have been suggested among the strategies to improve clinical outcomes with implanted medical devices [18].

A wide range of different implant materials are used in orthopedics. Despite the intensive research currently being performed on different technologies for incorporating antimicrobial agents [22-32], only a few studies investigating biofilm formation on different clinically relevant implantation materials have been published [33-38]. The dynamic changes associated with biofilm growth [39] make biofilm eradication from clinical materials even more challenging. As structural and functional features of biofilms are greatly dependent on the material and the biofilm growth conditions $[38,40,41]$, there is an obvious demand for comprehensive studies investigating the structural and functional features of the prosthetic materials together with biofilm dynamics on these materials. In this context, the cell surface-associated adhesins have attracted great interest, as many of these can contribute to protein-mediated biofilm formation [39,42-46]. Recently, an unacknowledged group of 
surface-associated proteins, i.a., moonlighting virulence factors and cytoplasmic proteins embedded in the staphylococcal biofilm matrix, was proposed to form a new molecular mechanism conferring increased stability for biofilm population [47]. High levels of intracellular cytoplasmic proteins and, to a much lesser extent, extracellular or cell-surface adhesins have also been identified from in vivo biofilm matrices using a rat model of orthopedic implant-associated chronic S. aureus infection [48]. Whether these moonlighters play a role during the formation of S. aureus biofilms on different prosthetic materials is not yet clear.

Thus, the aim of the present study was to compare the biofilm characteristics of a $S$. aureus biofilm-forming model strain ATCC 25923 (also known as strain Rosenbach or Seattle 1945) [49] on different clinically pertinent substrates, involving borosilicate glass, plexiglass, hydroxyapatite and titanium, using polystyrene as the reference material. Borosilicate glass $(\mathrm{G})$ has been traditionally used in artificial hip joints, bone cements, dental composite materials, prosthetic eyes and breast implants [50,51], while plexiglass (PG) is used in bone cements [52]. Joint implants are made of titanium alloys (TI) due to their biocompatibility and corrosion resistance, while hydroxyapatite (HA), a known mineral component of bones, is used to coat medical devices for improving the integration of the implant with newly formed bone [53]. The present study focused on (1) comparing the susceptibility of these clinically relevant surfaces to biofilm formation, (2) studying the time-dependent variations in exopolysaccharide and protein compositions of the biofilms on the indicated materials, and (3) identifying the core surfaceome (proteins present in all aged biofilms $(18,42$, and $66 \mathrm{~h})$ on every material) contributing to adherence/adherent growth. The present study demonstrates a number of material- and time point-dependent surfaceome changes. As a main finding, matrix-associated poly-N-acetyl- $\beta$-(1-6)-glucosamine (PNAG) was regarded as important in young (18 h) biofilms, whereas proteins had a more pivotal role at later stages of biofilm development.

\section{Materials and Methods}

\subsection{Materials}

Tryptic soy agar (TSA) and tryptic soy broth (TSB) were acquired from Lab M Limited (Lancashire, UK), while sucrose was from Merck (Darmstadt, Germany). Sequencing-grade modified trypsin (porcine) was purchased from Promega Corp. (Madison, WI, USA). Wheat germ agglutinin Alexa Fluor $^{\circledR} 488$ conjugate (WGA) was obtained from Invitrogen ${ }^{\mathrm{TM}}$, Thermo Fisher Scientific (Eugene, OR, USA). Dimethyl sulphoxide (DMSO) was purchased from VWR International (Fontenay-sous-Bois, France) and phosphate-buffered saline (PBS) was supplied by Lonza (Verviers, Belgium). Trifluoroacetic acid (99\%), triethylammonium bicarbonate buffer (TEAB; $1.0 \mathrm{M}, \mathrm{pH} 8.5)$, Tween ${ }^{\circledR} 20$, vancomycin hydrochloride hydrate, penicillin G sodium salt, levofloxacin and doxycycline hydrochloride were purchased from Sigma-Aldrich (Steinheim, Germany).

\subsection{Atomic Force Microscopy (AFM)}

The topography of the material surfaces (borosilicate glass, G; plexiglass, PG; hydroxyapatite, HA; titanium, TI and polystyrene, PS) was characterized with an NTegra Prima AFM (NT-MDT, Moscow, Russia) in an intermittent contact mode by using Au-coated NSG10 (NT-MDT, Moscow, Russia) probes with a nominal tip curvature radius of $10 \mathrm{~nm}$ and a force constant of 3.1-37.6 N/m. A scan rate of 0.3-0.5 Hz was used. Image analysis was conducted by using the Scanning Probe Image Processor software (SPIP, Image Metrology, Hørsholm, Denmark). Captured topographs were processed with Gaussian (ISO 11562) filtering.

\subsection{Bacterial Culture and Biofilm Formation}

The clinical strain Staphylococcus aureus ATCC 25923 was cultured in TSB at $37^{\circ} \mathrm{C}$ under aerobic conditions with shaking $(220 \mathrm{rpm})$ to reach the exponential phase, to a concentration of $10^{8} \mathrm{CFU} \cdot \mathrm{mL}^{-1}$. The bacterial concentration was estimated by measuring optical density at $595 \mathrm{~nm}$ (Varioskan ${ }^{\mathrm{TM}}$ 
LUX Multimode Microplate Reader, Thermo Scientific, Vantaa, Finland) and later confirmed by calculating colony-forming units (CFUs) on TSA plates. Biofilms were formed on 96-well plates (96-WPs) (Nunclon ${ }^{\mathrm{TM}} \Delta$ surface polystyrene plates, Nunc ${ }^{\mathrm{TM}}$, Roskilde, Denmark) or on coupons made of borosilicate glass (G), plexiglass (PG), titanium (TI) with dimensions: $0.4 \mathrm{~cm}$ height, $1.27 \mathrm{~cm}$ diameter; and hydroxyapatite (HA) with dimensions: $0.25 \mathrm{~cm}$ height, $1.27 \mathrm{~cm}$ diameter (BioSurface Technologies Corporation, Bozeman, MT, USA). For the experiments with coupons, they were placed in a polystyrene 12-WP (Costar ${ }^{\circledR}$, flat bottom, well diameter $2.26 \mathrm{~cm}$; Corning Inc., Corning, NY, USA). For the experiments performed in 12-WPs (with the coupons on them) or 96-WPs, $2.5 \mathrm{~mL}$ or $200 \mu \mathrm{L}$ of the bacterial suspension $\left(10^{6} \mathrm{CFU} \cdot \mathrm{mL}^{-1}\right)$ were used, respectively. The plates were incubated at $37^{\circ} \mathrm{C}$ under aerobic conditions with shaking (150 rpm) for 18,42 or $66 \mathrm{~h}$ (the incubation times were based on [54]). The media of the 42-h-old biofilms were changed after $18 \mathrm{~h}$ of incubation, whereas the media of the 66-h-old biofilms were refreshed at 18 and $42 \mathrm{~h}$.

\subsection{Quantification of Biofilm Formation on Different Materials}

S. aureus ATCC 25923 was grown on polystyrene (PS) (in 96-WP) or on borosilicate glass (G), plexiglass (PG), hydroxyapatite (HA) and titanium (TI) coupons in 12-WP, as described above. After 18, 42 or $66 \mathrm{~h}$, the biofilms formed on G, PG, HA or TI coupons were disaggregated for quantification as follows. First, the coupons were soaked in the medium (TSB) to detach planktonic and loosely attached bacteria, and then transferred into Falcon tubes of $50 \mathrm{~mL}$ containing $1 \mathrm{~mL}$ of $0.5 \%(w / v)$ Tween ${ }^{\circledR} 20$-TSB solution. In contrast, biofilms grown on 96-WPs were washed once with $200 \mu \mathrm{L}$ of TSB, and $200 \mu \mathrm{L}$ of Tween ${ }^{\circledR} 20-T S B$ solution was added on wells. The tubes and the $96-\mathrm{WPs}$ were sonicated in a water bath in Ultrasonic Cleaner 3800 (Branson Ultrasonics, Danbury, CT, USA) at $25^{\circ} \mathrm{C}, 35 \mathrm{kHz}$, for $5 \mathrm{~min}$. Serial dilutions $\left(10^{-1}-10^{-8}\right)$ were performed from the resulting bacterial suspensions onto TSA plates. Size differences between coupons and 96-WPs were taken into account by measuring colony-forming units (CFU) per volume $(\mathrm{mL})$ and area of bacterial attachment on the different surfaces $\left(\mathrm{cm}^{2}\right)$ and transforming the values of $\mathrm{CFU} \cdot\left(\mathrm{mL} \cdot \mathrm{cm}^{2}\right)^{-1}$ to a $\log _{10}$ scale.

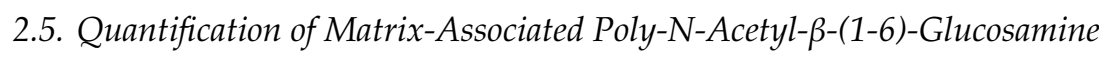

For quantifying matrix poly- $N$-acetyl- $\beta$-(1-6)-glucosamine (PNAG), S. aureus ATCC 25923 biofilms were grown in 96-WPs and on coupons in 12-WPs for 18, 42 and $66 \mathrm{~h}$, as described above. The previously reported WGA staining protocol [54] was applied with two modifications: a lower concentration $\left(2.5 \mu \mathrm{g} \cdot \mathrm{mL}^{-1}\right)$ of WGA conjugate was used based on [55] and $100 \%$ DMSO was used to replace $33 \%$ acetic acid, which is not compatible with acid-unbearable materials, such as HA. The selection of $100 \%$ DMSO was based upon initial tests where a lower concentration of acetic acid (10\% acetic acid), 96\% ethanol and $100 \%$ DMSO were tested (acquired assay quality parameters for DMSO: screening window coefficient $Z^{\prime}$ factor $=0.431$; signal to noise $(S / N)=5.4$; signal to background $\left.(\mathrm{S} / \mathrm{B})=9.2\right)$

First, the 96-WPs were washed once with $200 \mu \mathrm{L}$ of PBS, while the coupons were briefly soaked once in PBS, to detach planktonic and loosely attached cells. Then, WGA in PBS $\left(2.5 \mu \mathrm{g} \cdot \mathrm{mL}^{-1}\right)$ was added onto $96-W P s(200 \mu \mathrm{L})$ or onto coupons $(500 \mu \mathrm{L})$ in $24-\mathrm{WPs}$ (Nunclon ${ }^{\mathrm{TM}} \Delta$ surface, Nunc ${ }^{\mathrm{TM}}$, Roskilde, Denmark) and incubated in the darkness at $4{ }^{\circ} \mathrm{C}$ for $2 \mathrm{~h}$. After the incubation, the biofilms were washed three times with PBS and dried at room temperature (RT) for $15 \mathrm{~min}$. Next, $200 \mu \mathrm{L}$ of DMSO was added into the 96-WPs. The coupons were transferred into Falcon tubes of $50 \mathrm{~mL}$, containing $1.3 \mathrm{~mL}$ (for G, PG and TI) or $1.11 \mathrm{~mL}$ (for HA coupons; smaller volume was due to the smaller size of these coupons) of DMSO. The plates and the tubes were sonicated in a water bath at $25^{\circ} \mathrm{C}, 35 \mathrm{kHz}$, for $30 \mathrm{~s}$. Following an incubation at $37^{\circ} \mathrm{C}$ for $1 \mathrm{~h}$, the sonication step was repeated. Finally, $200 \mu \mathrm{L}$ of the remaining suspensions from Falcon tubes were transferred onto a 96-WP to measure top fluorescence with Varioskan ${ }^{\mathrm{TM}}$ LUX Multimode Microplate Reader $\left(\lambda_{\text {excitation }}=495 \mathrm{~nm}\right.$; $\lambda_{\text {emission }}=520 \mathrm{~nm}$ ). Before measuring the fluorescence signal from biofilms formed on 96-WPs, the resulting suspensions were diluted 1:10 to be in correspondence with the coupon surface area. 


\subsection{Fluorescence Imaging}

These experiments were performed with S. aureus ATCC 25923 biofilms grown on G coupons, stained with WGA as indicated above. After the 2-h-long incubation period $\left(4^{\circ} \mathrm{C}\right.$, in the darkness), the unbound dye was removed, and images of the coupons on Petri dishes were acquired with an Invitrogen $^{\mathrm{TM}}$ EVOS $^{\circledR}$ FL Imaging System (Life Technologies ${ }^{\mathrm{TM}}$, Eugene, OR, USA) using the Green Fluorescent Protein (GFP) light cube $\left(\lambda_{\text {excitation }}=470 / 22 \mathrm{~nm} ; \lambda_{\text {emission }}=510 / 42 \mathrm{~nm}\right)$ and a $20 \times$ objective.

\subsection{Trypsin Shaving of Matrix-Associated Proteins}

Before protein identification, biofilm viability with and without the trypsin treatment was first assessed to exclude possible effects of trypsin on biofilm integrity. Biofilms were grown on $\mathrm{G}$ coupons in 12-WPs and then transferred into Falcon tubes $(50 \mathrm{~mL})$ containing $1 \mathrm{~mL}$ of $100 \mathrm{mM}$ acetate buffer ( $\mathrm{pH}$ 4.7), a condition preventing the release of the adhesive moonlighting proteins [56]. The tubes were sonicated $\left(25^{\circ} \mathrm{C}, 35 \mathrm{kHz}, 5 \mathrm{~min}\right)$ and detached bacterial cells were collected by centrifugation $\left(4^{\circ} \mathrm{C}, 4000 \times g, 2 \mathrm{~min}\right)$. The cells were suspended in $110 \mu \mathrm{L}$ of $100 \mathrm{mM}$ TEAB containing $16 \%$ sucrose (TEAB-sucrose (16\%); $\mathrm{pH} 8.5$ ) with and without trypsin (at a final concentration of $51.9 \mathrm{ng} \cdot \mu \mathrm{L}^{-1}$ ), and the mixtures were incubated $\left(37^{\circ} \mathrm{C}, 15 \mathrm{~min}\right)$. Next, the cells were serially diluted in TSB and plated onto TSA to determine CFUs. The number of viable counts remained the same in both samples, excluding the possibility of trypsin-induced cell lysis (Figure S1) and confirming the suitability of the shaving conditions for trypsin shaving.

Biofilm cells for trypsin shaving were prepared in duplicates for each substrate and time point as follows. Biofilms attached to coupons were first rinsed with TSB to remove planktonic bacteria and transferred onto 12-WPs. There, the cells were scraped off from the coupon surface into $100 \mathrm{mM}$ acetate buffer $\left(4^{\circ} \mathrm{C}, \mathrm{pH} 4.7\right)$ using a sterile plastic stick. In the case of biofilms formed on PS, the biofilms were also rinsed with TSB first and scraped off from 96-WPs into $100 \mathrm{mM}$ acetate buffer. In all cases, cells were collected by centrifugation $\left(4{ }^{\circ} \mathrm{C}, 4000 \times g, 2 \mathrm{~min}\right)$ and suspended in $110 \mu \mathrm{L}$ of $100 \mathrm{mM}$ TEAB-sucrose (16\%) [57] and trypsin (at a final concentration of $51.9 \mathrm{ng} \cdot \mu \mathrm{L}^{-1}$ ). After the trypsin treatment $\left(37^{\circ} \mathrm{C}, 15 \mathrm{~min}\right)$, cells were first removed by centrifugation (RT, 4000× $\left.g, 2 \mathrm{~min}\right)$ and digestions were further purified through cellulose acetate membranes (pore size $0.22 \mu \mathrm{m}, \mathrm{Costar}^{\circledR}$ Spin-X Centrifuge Tube Filter, Corning Inc., Corning, NY, USA) by centrifugation (RT, 16000× $g$, $2 \mathrm{~min}$ ). Digestions incubated at $37^{\circ} \mathrm{C}$ for $16 \mathrm{~h}$ were blocked by adding trifluoroacetic acid to a final concentration of $0.6 \%$. Concentrations of released proteins/peptides were measured using low-volume photometric quantification at $280 \mathrm{~nm}$, with a $\mu$ Drop $^{\mathrm{TM}}$ Plate (Thermo Scientific, Vantaa, Finland) on a Varioskan $^{\mathrm{TM}}$ LUX Multimode Reader (Thermo Scientific, Vantaa, Finland).

\subsection{Identification of Trypsin-Released Proteins/Peptides by LC-MS/MS}

Tryptic peptides were purified and concentrated using ZipTips (C18; Millipore ${ }^{\circledR}$, Merck KGaA, Darmstadt, Germany) and peptides were analyzed essentially as described previously [58]. Briefly, an equal amount of the purified tryptic peptides was submitted to an Easy-nLC 1000 Nano-LC system (Thermo Scientific, Vantaa, Finland) coupled to a quadrupole Orbitrap mass spectrometer (Q Exactive ${ }^{\mathrm{TM}}$, Thermo Scientific, Bremen, Germany) equipped with a nanoelectrospray ion source (Easy-Spray $^{\mathrm{TM}}$, Thermo Scientific, Vantaa, Finland). Liquid chromatography separation was performed in an Easy-Spray ${ }^{\mathrm{TM}}$ column of $25 \mathrm{~cm}$ bed length $(\mathrm{C} 18,2 \mu \mathrm{m}$ beads, $100 \AA$, $75 \mu \mathrm{m}$ inner diameter, Thermo Scientific), using a flow rate of $300 \mathrm{~nL} / \mathrm{min}$. The peptides were eluted with a $2-30 \%$ gradient of solvent (composed of $100 \%$ acetonitrile and $0.1 \%$ formic acid) in $60 \mathrm{~min}$. Acquired MS raw data were processed using the MaxQuant version 1.6.2.1 [59] with built-in Andromeda search engine [60]. Database searches were conducted against the UniProt S. aureus protein database (https://www.uniprot.org/). In these searches, carbamidomethyl (C) was set as a fixed and methionine oxidation as a variable modification. First search peptide tolerance of $20 \mathrm{ppm}$ and main search error of $4.5 \mathrm{ppm}$ were used. Trypsin without proline restriction enzyme option was used, with two allowed miscleavages. The minimal unique 
+ razor peptides number was set to 1, and FDR to 0.01 (1\%) for peptide and protein identification. Known contaminants provided by MaxQuant, and proteins identified as "reverse" and "only identified by site" were discarded from further data analyses. Only proteins that could be identified in both replica samples were included in data set comparisons.

\subsection{Chemotolerance Assays}

S. aureus ATCC 25923 biofilms were grown on HA and TI coupons in 12-WPs for 18 and $66 \mathrm{~h}$, as previously described in Section 2.3. After the incubation, the chemotolerance assay was performed essentially as described previously [28]. The coupons were soaked in TSB to detach planktonic cells and transferred onto 12-WPs containing $2.5 \mathrm{~mL}$ of $2.0 \mu \mathrm{M}$ penicillin $\mathrm{G}(0.71 \mu \mathrm{g} / \mathrm{mL}), 90.0 \mu \mathrm{M}$ levofloxacin $(32.5 \mu \mathrm{g} / \mathrm{mL}), 4.0 \mu \mathrm{M}$ doxycycline $(1.92 \mu \mathrm{g} / \mathrm{mL})$ or $5.0 \mu \mathrm{M}$ vancomycin $(7.43 \mu \mathrm{g} / \mathrm{mL})$ or TSB (as a negative control). The coupons were exposed to the indicated antibiotics for 2 or $24 \mathrm{~h}$ at $37^{\circ} \mathrm{C}$, under aerobic conditions with shaking (150 rpm). After the treatment, biofilms were quantified as in Section 2.4. A combination treatment involving trypsin $\left(51.9 \mathrm{ng} \cdot \mu \mathrm{L}^{-1}\right)$ and $90 \mu \mathrm{M}$ levofloxacin was also tested. Therein, biofilms were formed on HA for 18 and $66 \mathrm{~h}$, as above. After the incubation periods, the coupons were soaked in TSB and transferred onto a 24-WP containing trypsin in buffer ( $35 \mu \mathrm{L}$ of trypsin in $350 \mu \mathrm{L}$ of $100 \mathrm{mM}$ TEAB-sucrose $(16 \%)$ ) or mere buffer ( $385 \mu \mathrm{L}$ of $100 \mathrm{mM}$ TEAB-sucrose $(16 \%)$, as a negative control). The 24-WPs were incubated at $37^{\circ} \mathrm{C}$ for $15 \mathrm{~min}$, as described in Section 2.7. Next, the coupons were soaked in TSB, and transferred onto the 12-WP containing $2.5 \mathrm{~mL}$ of $90 \mu \mathrm{M}$ levofloxacin. The coupons were incubated with the antibiotic at $37^{\circ} \mathrm{C}$ under aerobic conditions with shaking $(150 \mathrm{rpm})$ for $24 \mathrm{~h}$. As a second control, biofilms were grown in TSB under similar conditions for $24 \mathrm{~h}$ and $15 \mathrm{~min}$. Biofilm formation on the materials was assessed as in Section 2.4. The anti-biofilm effect of the antibiotics is expressed as a logarithmic reduction of the bacterial burden [61], using Equation (1):

$$
\log R=\log _{10}\left\langle(C F U / m L)_{c o n t r o l}\right\rangle-\log _{10}\left\langle(C F U / m L)_{\text {compound }}\right\rangle
$$

where $\langle\cdot\rangle$ denotes averaging over samples.

\subsection{Data Processing and Statistical Analysis}

For the optimization of the WGA staining protocol (Section 2.5), the following statistical parameters were used: screening window coefficient $Z^{\prime}$ factor, signal to noise $(S / N)$ and signal to background $(S / B)$ (according to Equations (2)-(4)) [54,62,63].

$$
\begin{gathered}
Z^{\prime}=1-\frac{\left(3 \times S D_{\max }+3 \times S D_{\min }\right)}{\left|X_{\max }-X_{\min }\right|} \\
\frac{S}{N}=\frac{X_{\max }-X_{\text {min }}}{\left(S D_{\max }^{2}+S D_{\text {min }}{ }^{2}\right)^{1 / 2}} \\
\frac{S}{B}=\frac{X_{\text {max }}}{X_{\text {min }}}
\end{gathered}
$$

One-way analysis of variance comparisons and Tukey (for equal variances) and Games-Howell (for unequal variances) post-tests were executed using IBM SPSS Statistics (SPSS Inc., Chicago, IL, USA, version 24.0 for Windows). In paired comparisons, the unpaired t-test with Welch's correction was used (GraphPad Software, Prism, La Jolla, CA, USA, version 7.0 for Windows). $p<0.05$ was considered statistically significant and $p<0.001$ statistically highly significant. Each test was performed at least in duplicate.

SPSS was also used in multivariate statistical analyses of the protein identification data, using average relative intensity values obtained for proteins identified in both biological replicates. The values of the commonly identified proteins were $\log _{2}$-transformed, and principle component analysis (PCA; based on the correlation matrix) was performed using Oblimin rotation with Kaiser Normalization. 


\section{Results}

\subsection{HA and PG Exhibited the Largest Surface Roughness}

AFM topographical images of 96-well plates (made of polystyrene; PS) and borosilicate glass (G), plexiglass (PG), hydroxyapatite (HA) and titanium (TI) coupons are shown in Figure 1. Materials PG and HA are the most heterogeneous and uneven surfaces, whereas TI, PS and G appear to be much smoother. Roughness analysis of the AFM images provided more quantitative insights into the differences between the substrates (Table 1 and Figure S2). The surface area ratio $\left(S_{\mathrm{dr}}\right)$ describes the roughness-induced increment of the interfacial surface area relative to the area of the projected flat plane, while $V_{V}$ illustrates the void volume, describing surface porosity. The surfaces of HA and PG showed the largest roughness values $\left(S_{d r}=58 \pm 10 \%\right.$ and $123 \pm 20 \% ; V_{v}=0.75 \pm 0.08 \mu \mathrm{m}^{3} / \mu \mathrm{m}^{2}$ and $0.62 \pm 0.07 \mu \mathrm{m}^{3} / \mu \mathrm{m}^{2}$, respectively) (Table 1). The smoothest surface was observed to be $G\left(S_{d r}=0.3 \pm 0.1 \% ; V_{v}=0.0048 \pm 0.001 \mu \mathrm{m}^{3} / \mu \mathrm{m}^{2}\right)$. The same trend was observed with length-scale dependent roughness (Figure S2).

Table 1. Selected roughness parameters of materials used in the assays. $\mathrm{S}_{\mathrm{dr}}$ describes the relative increase in surface area compared to the flat surface. $V_{v}$ reflects void volume, describing the openness of the surface or surface porosity.

\begin{tabular}{ccc}
\hline Material & $\mathbf{S}_{\mathbf{d r}}(\mathbf{\%})$ & $\mathbf{V}_{\mathbf{v}}\left(\mu_{\mathbf{m}^{3}} / \mu_{\left.\mathbf{m}^{2}\right)}\right.$ \\
\hline Borosilicate glass & $0.3 \pm 0.1$ & $0.0048 \pm 0.001$ \\
Plexiglass & $123 \pm 20$ & $0.62 \pm 0.07$ \\
Hydroxyapatite & $58 \pm 10$ & $0.75 \pm 0.08$ \\
Titanium & $9.0 \pm 1.1$ & $0.19 \pm 0.02$ \\
Polystyrene & $3.0 \pm 0.4$ & $0.012 \pm 0.002$ \\
\hline
\end{tabular}

\subsection{The Most Significant Time-Dependent Increase in Biofilm Formation Was Detected on HA}

Attachment of $S$. aureus ATCC 25923 onto all five materials was compared at three incubation time points $\left(18,42\right.$ and $66 \mathrm{~h}$ ). The number of attached bacteria was expressed as $\log _{10}$ of viable $\mathrm{CFU} \cdot\left(\mathrm{mL} \cdot \mathrm{cm}^{2}\right)^{-1}$. In the assay conditions, viable colonies increased temporally in a statistically significant manner only in two cases (PG and HA; from 18 to $42 \mathrm{~h}$ ), while a non-significant trend implying temporal decrease in cell viability was observed with biofilms on G and TI (Figure 2). Comparisons between different materials at similar time points showed that S. aureus ATCC 25923 was more prone to form biofilms on PS than on the other substrates. In addition, biofilm formation on PS was equally high after 18,42 or $66 \mathrm{~h}$.

\subsection{Temporal Decrease in the Total PNAG Amount Was Detected in All Biofilms}

The exopolysaccharide amount was studied using a wheat germ agglutinin (WGA) conjugate that targets the poly-N-acetyl- $\beta-(1-6)$-glucosamine (PNAG) fraction of the biofilm matrix. Using the optimized staining conditions (described in Section 2.5), 18-, 42- and 66-h-old S. aureus ATCC 25923 biofilms were treated with WGA conjugate, after being formed on the indicated five substrate materials. The PS-associated biofilms contained statistically more $(p<0.05)$ PNAG fraction than biofilms formed on G, PG or TI (Figure 3). A temporal decline (from 18 to $66 \mathrm{~h}$ ) in the PNAG fraction was noted for all the tested substrate materials; the deepest decline was detected with biofilms on TI. The images presented in Figure 4 confirm the declining trend for PNAG in 18- versus 42-h-old biofilms on G coupons, and illustrate the macrostructural temporal evolution from thick, intermittent regions (Figure $4 \mathrm{~A} ; 18 \mathrm{~h}$ ) to a thinner, more cohesive PNAG network (Figure 4B; $42 \mathrm{~h}$ ). 

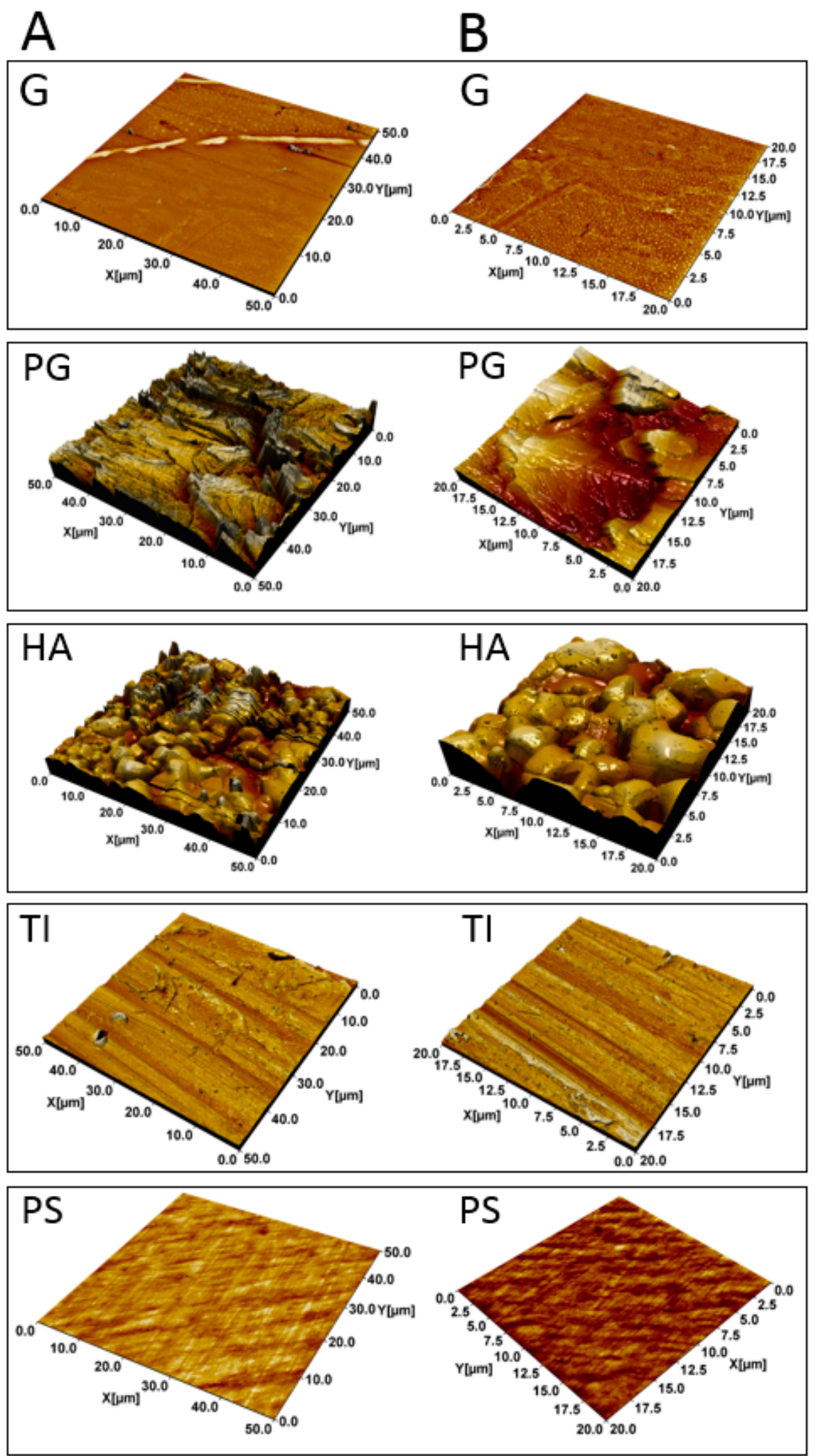

Figure 1. Atomic Force Microscopy (AFM) topographical images of the materials. Borosilicate glass (G), plexiglass (PG), hydroxyapatite (HA), titanium (TI) and polystyrene (PS) captured with the image size of $50 \times 50 \mu \mathrm{m}$ (A). Zoomed images of the materials with the size of $20 \times 20 \mu \mathrm{m}(\mathbf{B})$. 


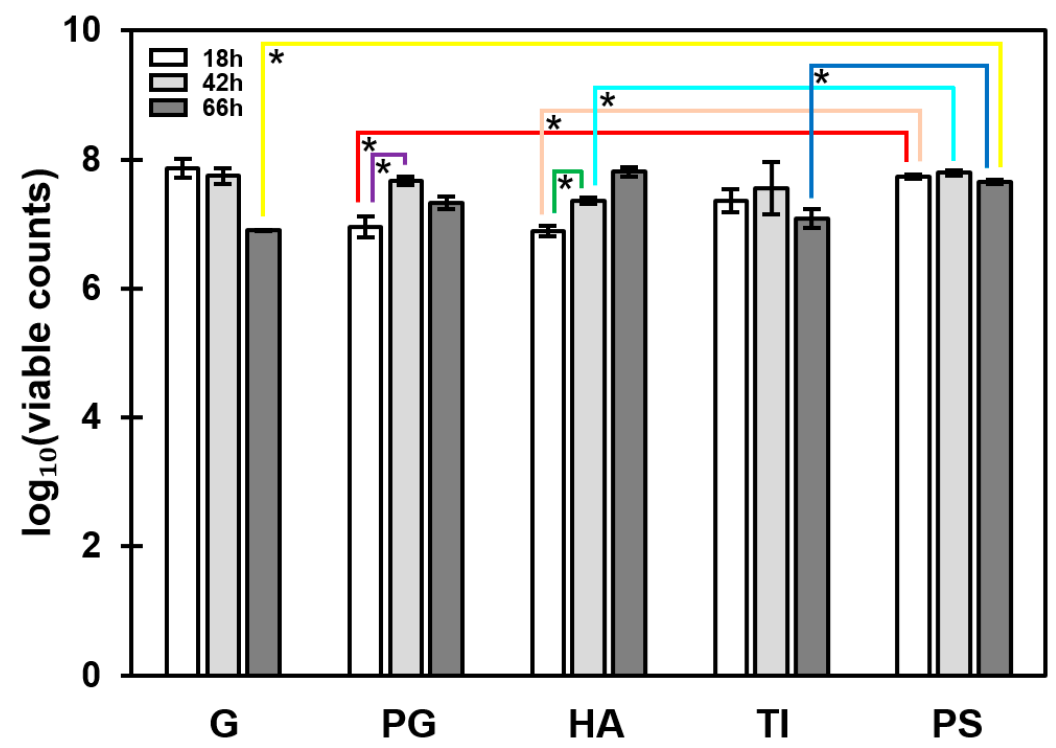

Figure 2. Formation of Staphylococcus aureus ATCC 25923 on five substrate materials. Bacterial attachment is expressed as $\log _{10}$ values of CFU. $\left(\mathrm{mL} \cdot \mathrm{cm}^{2}\right)^{-1}$. Differences in attachment were assessed for a single material between different time points, and for a fixed time point between the different materials, using one-way ANOVA with Games-Howell post-test. ${ }^{*}$, significant difference $(p<0.05)$. Error bars denote the standard error of the mean (SEM) $(n=3) . \mathrm{G}$, borosilicate glass; PG, plexiglass; HA, hydroxyapatite; TI, titanium; PS, polystyrene.

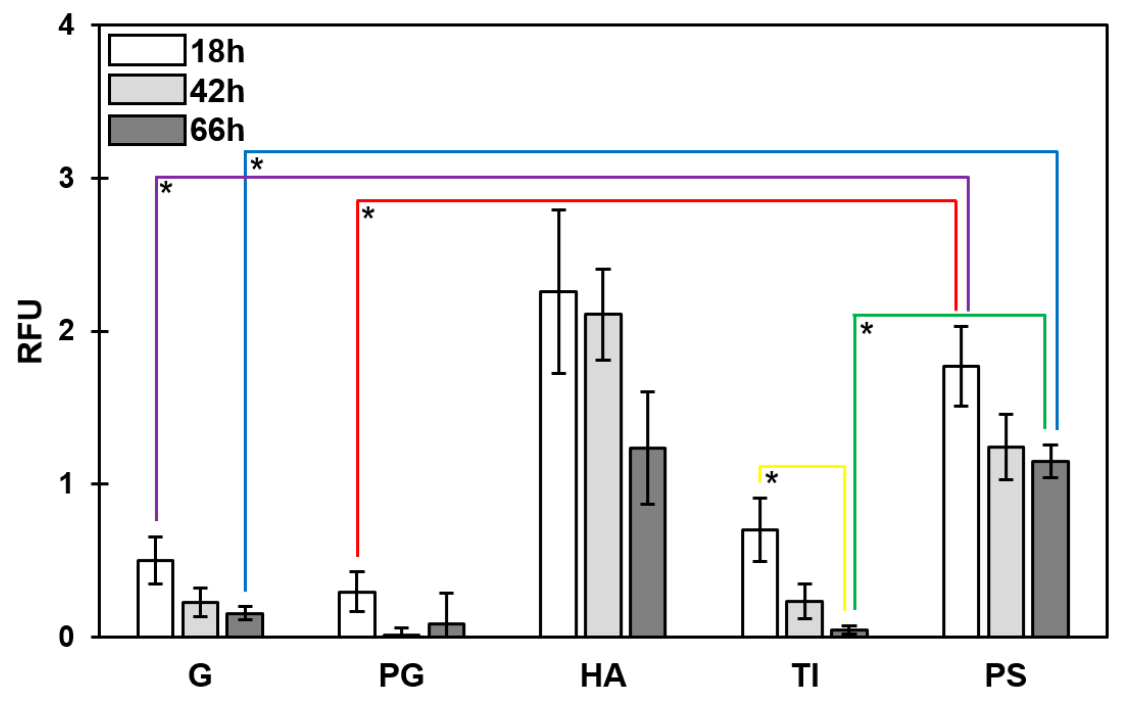

Figure 3. Wheat germ agglutinin Alexa Fluor ${ }^{\circledR} 488$ conjugate-based quantification of poly- $N$-acetyl$\beta$-(1-6)-glucosamine (PNAG) in S. aureus ATCC 25923. Differences in PNAG contents (expressed as relative fluorescence units (RFUs)) were assessed for a single material between different time points, and for a fixed time point between the different materials, using one-way ANOVA comparisons and Games-Howell post-tests for blank-corrected data points. ${ }^{*}$, significant difference $(p<0.05)$. Error bars denote the standard error of the mean (SEM) $(n=2)$. G, borosilicate glass; PG, plexiglass; HA, hydroxyapatite; TI, titanium; PS, polystyrene. 

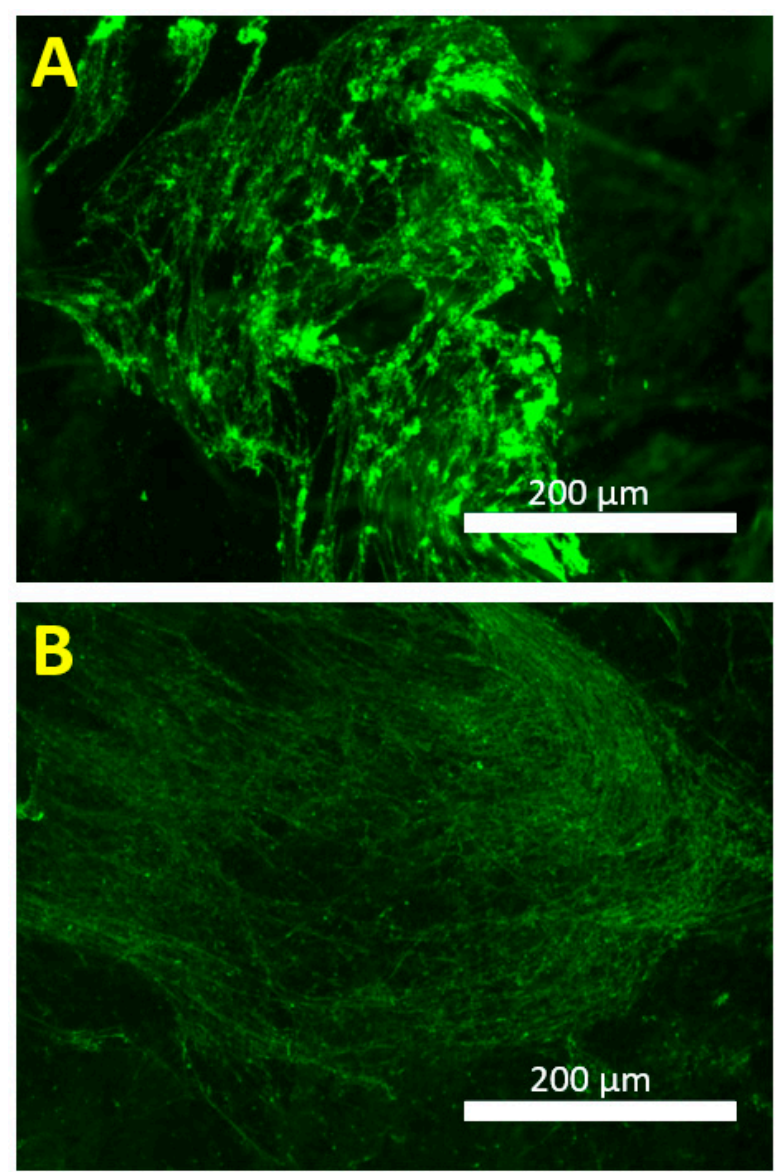

Figure 4. WGA-Alexa Fluor ${ }^{\circledR} 488$ fluorescent conjugate-based imaging of the 18- (A) and 42-h-old (B) S. aureus ATCC 25923 biofilm matrix. Biofilms were formed on borosilicate glass coupons and the images were taken using Invitrogen ${ }^{\mathrm{TM}}$ EVOS $^{\circledR}$ FL Imaging System.

\subsection{A Total of 66 Proteins Were Shared by All Biofilms}

The protein concentration and the number of proteins were first examined in all biofilm matrices at the indicated time points $(18,42$ and $66 \mathrm{~h})$. The clearest trend in time-dependent increase in the total protein concentration was detected for biofilms formed on G and HA (Figure 5A). For the PG- and PS-associated biofilms, the highest protein concentration was reached at the $42 \mathrm{~h}$ time point, although later declined at $66 \mathrm{~h}$ in both cases.

Next, all the individual proteins were identified from the biofilm samples by trypsin shaving and LC-MS/MS analyses. The combined surfaceome catalogs based on two independent experiments enabled the identification of 460 proteins in total. An obvious trend of temporal increase in the number of the identified proteins was observed with biofilms formed on HA and TI (Figure 5B). At the $18 \mathrm{~h}$ time point, the highest number of proteins was identified from biofilms formed on PS (390 proteins), and the lowest number with the biofilms formed on TI (76 proteins). The core surfaceomes (i.a., protein orthologs shared by all samples) defined for biofilms growing on different materials at a fixed time point indicated 67,220 and 347 proteins that were shared by all 18, 42 and $66 \mathrm{~h}$ time point biofilms, respectively (Figure 6A). The number of proteins common to all biofilms (detected on every material at every time point) was 66 (Figure 6B). The highest number of proteins shared by all time points in fixed materials was obtained with the PG and PS biofilms (PG, 329 proteins; PS, 383 proteins) (Figure S3). 

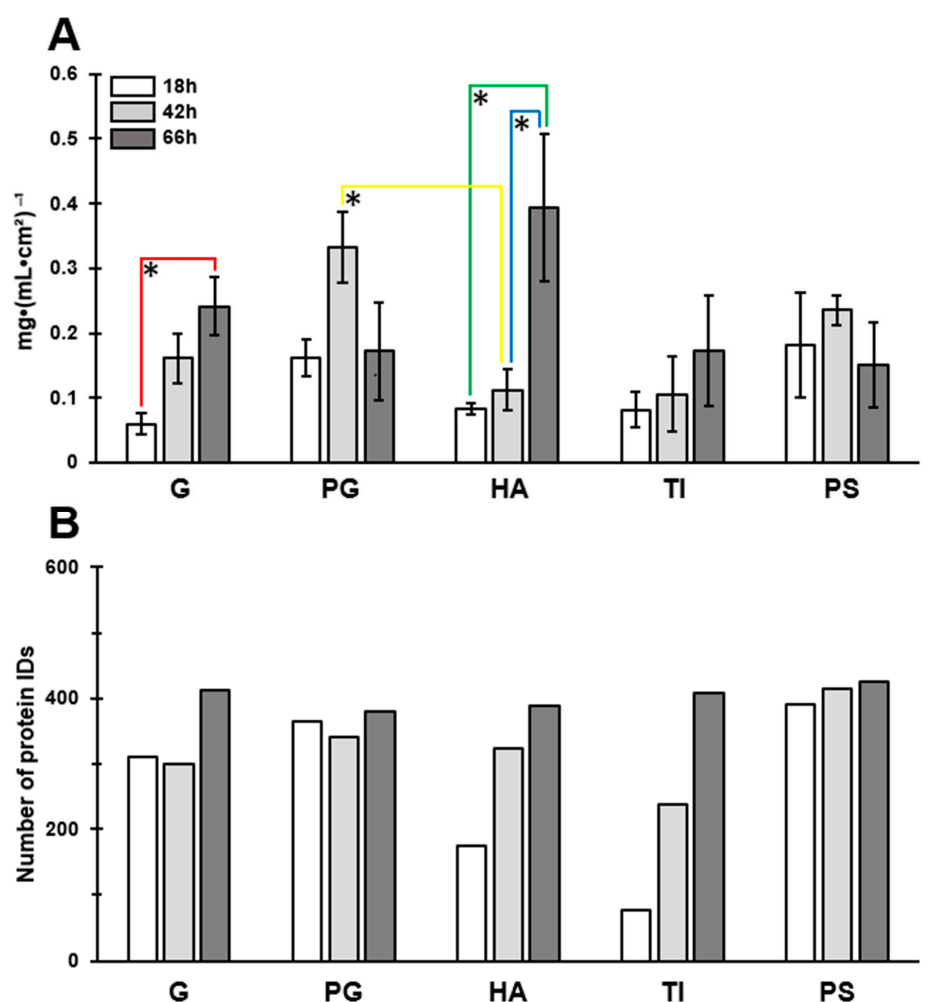

Figure 5. Protein concentrations $\mathrm{mg} \cdot\left(\mathrm{mL} \cdot \mathrm{cm}^{2}\right)^{-1}(\mathbf{A})$ and the number of the identified matrix-associated proteins (detected in both replicates) (B) of the S. aureus ATCC 25923 biofilms. Differences in protein concentrations were assessed for a single material between different time points, and for a fixed time point between the different materials, using one-way ANOVA comparisons and Tukey post-tests for blank-corrected data points. *, significant difference $(p<0.05)$. Error bars denote the standard error of the mean (SEM) $(n=2)$. G, borosilicate glass; PG, plexiglass; HA, hydroxyapatite; TI, titanium; PS, polystyrene.

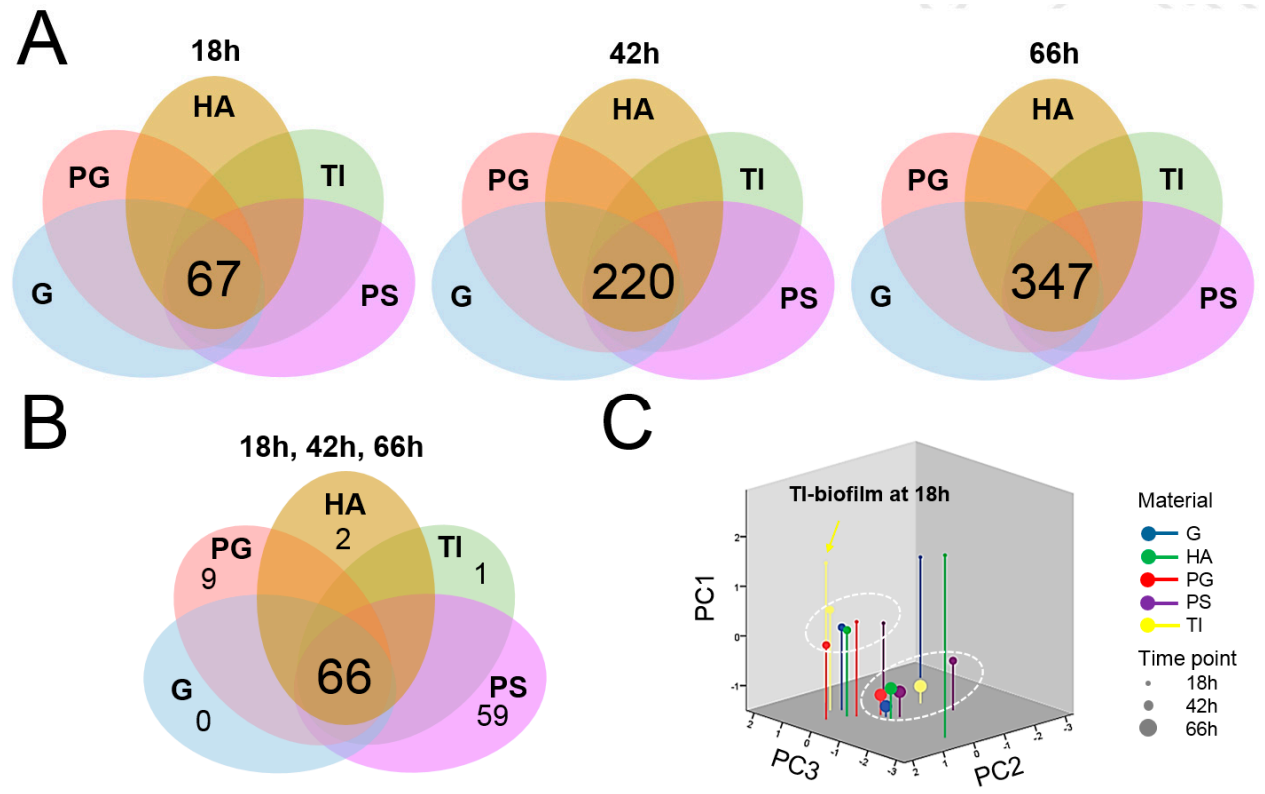

Figure 6. Venn diagrams representing the shared surfaceome proteins present on all materials at fixed time points of growth (A) and the number of all identified proteins shared by each biofilm and material combination and time point (B). A three-dimensional principle component analysis (3D PCA) analysis indicating outliers and clusters (circled) nested within the identified material- and time-dependent biofilm surfaceomes $(\mathbf{C})$. 


\subsection{Protein Moonlighters Formed the Largest Fraction of the Core Surfaceome}

Dynamics of relative protein abundance changes in each formed biofilm over time was investigated next by three-dimensional principal component analysis (3D PCA). Figure 6C shows two major clusters; the $42 \mathrm{~h}$ PS biofilm surfaceome together with those formed on each five materials for $66 \mathrm{~h}$, while the rest of the $42 \mathrm{~h}$ biofilm surfaceomes (G, HA, PG and TI) and those associated with PG- and PS at the $18 \mathrm{~h}$ time point formed the second cluster. Biofilms formed on TI-, G- and HA-coupons at the $18 \mathrm{~h}$ time point were clearly separated from the two main clusters, implying that these three materials affected the adherence in young biofilms (during $18 \mathrm{~h}$ ). Altogether, the 3D PCA analysis revealed that TI, G and HA promoted specific surfaceome changes in biofilms already at the $18 \mathrm{~h}$ time point.

Table 2 illustrates changes in protein abundances in relation to time and different substrates. The most dominating proteins in all materials and time points were identified either as known or potential moonlighting proteins. Among these, the ribosomal proteins (r-proteins) formed the biggest group. Other moonlighters identified in all materials and time points included enzymes with a role in glycolysis (enolase (ENO); glyceraldehyde-3-phosphate dehydrogenase (GaPDH); triosephosphate isomerase (TPI); pyruvate kinase (PYK); pyruvate dehydrogenase E1 (PDHB); phosphoglycerate kinase (PGK); L-lactate dehydrogenase 1 (L-LDH) and alcohol dehydrogenase (ADH)), protein synthesis (elongation factor Tu (EfTU); elongation factor G (EfG) and elongation factor P (EfP)), and stress (chaperone protein (DnaK); universal stress protein (SAV1710), Usp and alkyl hydroperoxide reductase $(\mathrm{AhpC})$ ). Among these, the predicted abundances of EfTU, PGK, ENO and GaPDH reached the highest level at $66 \mathrm{~h}$, which clearly exceeded those detected for the r-proteins. The Clp family proteins (ClpP, ClpL, ClpC and ClpB) also displayed material-dependent variation; their abundances displayed temporal increase in all biofilm matrices. The Clp proteins were not detected at the $18 \mathrm{~h}$ time point of TI.

Table 2. A heatmap comparing the intensity values $\left(\log _{10}\right)$ of selected protein identification.

\begin{tabular}{|c|c|c|c|c|c|c|c|c|c|c|c|c|c|c|c|c|}
\hline \multirow{2}{*}{ Protein Name } & \multirow{2}{*}{ Acc. No. ${ }^{\text {a }}$} & \multicolumn{5}{|c|}{$18 \mathrm{~h}$} & \multicolumn{5}{|c|}{$42 \mathrm{~h}$} & \multicolumn{5}{|c|}{$66 \mathrm{~h}$} \\
\hline & & PS & G & HA & PG & TI & PS & G & HA & PG & TI & PS & G & HA & PG & TI \\
\hline Bifunctional autolysin-AtlA & Q6GI31 & & & & & & & & & & & & & & & \\
\hline Immunoglobulin G-binding protein $\mathrm{A}-\mathrm{Spa}$ & P38507 & & & & & & & & & & & & & & & \\
\hline Immunoglobulin-binding protein-Sbi & Q6GE15 & & & & & & & & & & & & & & & \\
\hline Immunodominant antigen B-IsaB & Q6GDG4 & & & & & & & & & & & & & & & \\
\hline Immunodominant antigen A-IsaA & Q6GDN1 & & & & & & & & & & & & & & & \\
\hline Malate:quinone oxidoreductase $2-\mathrm{MQO} 2$ & Q6GDJ6 & & & & & & & & & & & & & & & \\
\hline Leukocidin-like protein 2-Luk2 & Q6GF49 & & & & & & & & & & & & & & & \\
\hline Leukocidin-like protein 1-Luk1 & Q6GF50 & & & & & & & & & & & & & & & \\
\hline Non-heme ferritin-FtnA & Q99SZ3 & & & & & & & & & & & & & & & \\
\hline Foldase protein $\mathrm{A}-\operatorname{Prs} \mathrm{A}$ & Q6GFL5 & & & & & & & & & & & & & & & \\
\hline Thioredoxin & Q6GHU0 & & & & & & & & & & & & & & & \\
\hline Staphylococcal secretory antigen-SsaA & Q99RX4 & & & & & & & & & & & & & & & \\
\hline Putative dipeptidase SAR1836 & Q6GFV0 & & & & & & & & & & & & & & & \\
\hline Clp protease proteolytic subunit $-\mathrm{ClpP}$ & Q6GIM3 & & & & & & & & & & & & & & & \\
\hline Clp ATPase ClpC & Q99W78 & & & & & & & & & & & & & & & \\
\hline Clp ATPase ClpL & Q6GDQ0 & & & & & & & & & & & & & & & \\
\hline Clp ATPase ClpB & Q6GIB2 & & & & & & & & & & & & & & & \\
\hline Gamma-hemolysin component B-HlgB & Q6GE12 & & & & & & & & & & & & & & & \\
\hline Protein RecA & Q6GHF0 & & & & & & & & & & & & & & & \\
\hline Bone sialoprotein-binding protein-Bbp & Q6GJA6 & & & & & & & & & & & & & & & \\
\hline Clumping factor $\mathrm{B}-\mathrm{ClfB}$ & Q6GDH2 & & & & & & & & & & & & & & & \\
\hline Clumping factor $\mathrm{A}-\mathrm{ClfA}$ & Q6GIK4 & & & & & & & & & & & & & & & \\
\hline Delta-hemolysin-HglD & Q6GF37 & & & & & & & & & & & & & & & \\
\hline Virulence factor-EsxA & Q99WU4 & & & & & & & & & & & & & & & \\
\hline ATP-dependent protease ATPase-HsIU & Q6GHI1 & & & & & & & & & & & & & & & \\
\hline Elastin-binding protein-EbpS & Q6GGT1 & & & & & & & & & & & & & & & \\
\hline Fibrinogen-binding protein-FbnBP & Q6GHS9 & & & & & & & & & & & & & & & \\
\hline Fibronectin-binding protein A-FnBPA & Q6GDU5 & & & & & & & & & & & & & & & \\
\hline Ser-Asp repeat-containing protein $\mathrm{C}-\mathrm{SdrC}$ & Q6GJA7 & & & & & & & & & & & & & & & \\
\hline Ser-Asp repeat-containing protein $\mathrm{D}-\mathrm{SdrD}$ & Q8NXX6 & & & & & & & & & & & & & & & \\
\hline Catabolite control protein $\mathrm{A}-\mathrm{CcpA}$ & Q6GFX2 & & & & & & & & & & & & & & & \\
\hline
\end{tabular}


Table 2. Cont.

\begin{tabular}{|c|c|c|c|c|c|c|c|c|c|c|c|c|c|c|c|c|}
\hline \multirow{2}{*}{ Protein Name } & \multirow{2}{*}{ Acc. No. ${ }^{a}$} & \multicolumn{5}{|c|}{$18 \mathrm{~h}$} & \multicolumn{5}{|c|}{$42 \mathrm{~h}$} & \multicolumn{5}{|c|}{$66 \mathrm{~h}$} \\
\hline & & PS & G & HA & PG & TI & PS & G & HA & PG & TI & PS & G & HA & PG & TI \\
\hline Response regulator-CodY & Q6GHI0 & & & & & & & & & & & & & & & \\
\hline Response regulator-SarA & Q7A732 & & & & & & & & & & & & & & & \\
\hline Response regulator-Rot & Q9RFJ6 & & & & & & & & & & & & & & & \\
\hline Response regulator-SarR & Q9F0R1 & & & & & & & & & & & & & & & \\
\hline Response regulator-SarS & Q7A872 & & & & & & & & & & & & & & & \\
\hline Response regulator-VraR & Q7A4R9 & & & & & & & & & & & & & & & \\
\hline Response regulator-SaeR & Q99VR7 & & & & & & & & & & & & & & & \\
\hline Response regulator-MsrR & Q99Q02 & & & & & & & & & & & & & & & \\
\hline Response regulator-MraZ & Q6GHQ7 & & & & & & & & & & & & & & & \\
\hline Response regulator-LytR & P52078 & & & & & & & & & & & & & & & \\
\hline Response regulator- $\mathrm{NrdR}$ & Q6GG20 & & & & & & & & & & & & & & & \\
\hline Response regulator-GraR & Q6GJ11 & & & & & & & & & & & & & & & \\
\hline HTH-type transcriptional regulator-MgrA & Q99VT5 & & & & & & & & & & & & & & & \\
\hline Redox-sensing repressor-Rex & Q6GF26 & & & & & & & & & & & & & & & \\
\hline SOS response repressor-LexA & Q9L4P1 & & & & & & & & & & & & & & & \\
\hline Oxygen regulatory protein $-\mathrm{NreC}$ & Q99RN8 & & & & & & & & & & & & & & & \\
\hline Regulatory protein-Spx & Q6GI88 & & & & & & & & & & & & & & & \\
\hline Histidine protein kinase-SaeS & Q99VR8 & & & & & & & & & & & & & & & \\
\hline RNA polymerase sigma factor SigA & Q99TT5 & & & & & & & & & & & & & & & \\
\hline Anti-sigma-B factor antagonist-RsbV & Q6GF07 & & & & & & & & & & & & & & & \\
\hline Iron-regulated surface determinant-IsdB & Q6GHV7 & & & & & & & & & & & & & & & \\
\hline Lysostaphin resistance protein A-LyrA & Q6GEA0 & & & & & & & & & & & & & & & \\
\hline Methicillin-resistance protein_FmtA & Q6GI27 & & & & & & & & & & & & & & & \\
\hline Conserved virulence factor B-CvfB & Q99U93 & & & & & & & & & & & & & & & \\
\hline DegV domain-containing protein SAR1438 & Q6GGY2 & & & & & & & & & & & & & & & \\
\hline Signal transduction protein TRAP & Q6GFM2 & & & & & & & & & & & & & & & \\
\hline Staphopain A (cysteine protease)-SspP & Q6GFE8 & & & & & & & & & & & & & & & \\
\hline Ferrochelatase-HemH & Q6G8A3 & & & & & & & & & & & & & & & \\
\hline Phospholipase C-PIC & Q5HEI1 & & & & & & & & & & & & & & & \\
\hline Methicillin resistance-associated-FemA & Q99UA7 & & & & & & & & & & & & & & & \\
\hline Methicillin resistance-associated-FemB & Q6GH30 & & & & & & & & & & & & & & & \\
\hline Probable cell wall amidase- - LytH & Q7A588 & & & & & & & & & & & & & & & \\
\hline ATP-dependent protease subunit-HslV & Q6GHI2 & & & & & & & & & & & & & & & \\
\hline CtpA-like serine protease & Q6GGY8 & & & & & & & & & & & & & & & \\
\hline HtrA-like serine protease & Q6GI62 & & & & & & & & & & & & & & & \\
\hline Hydrolase encoded by the agr operon & P55177 & & & & & & & & & & & & & & & \\
\hline Probable thiol peroxidase & Q6GFZ4 & & & & & & & & & & & & & & & \\
\hline Uncharacterized oxidoreductase SAR2567 & Q6GDV6 & & & & & & & & & & & & & & & \\
\hline Peptide methionine sulfoxide reductase MsrB & Q6GGY4 & & & & & & & & & & & & & & & \\
\hline Heme-dependent peroxidase (SAV0587) & Q99W24 & & & & & & & & & & & & & & & \\
\hline Thioredoxin reductase & Q6GB66 & & & & & & & & & & & & & & & \\
\hline NADPH-dependent oxidoreductase & Q6GJR6 & & & & & & & & & & & & & & & \\
\hline Multicopper oxidase-Mco & Q6GIX3 & & & & & & & & & & & & & & & \\
\hline Nitric oxide synthase oxygenase & Q6GFE2 & & & & & & & & & & & & & & & \\
\hline Putative NAD $(\mathrm{P}) \mathrm{H}$ nitroreductase (SAV2523) & Q99RB2 & & & & & & & & & & & & & & & \\
\hline FMN-dependent NADPH-azoreductase & Q99W49 & & & & & & & & & & & & & & & \\
\hline Staphylocoagulase-Coa & P17855 & & & & & & & & & & & & & & & \\
\hline Iron-sulfur cluster repair protein-ScdA & Q6GK53 & & & & & & & & & & & & & & & \\
\hline Urease accessory protein G-UreG & Q99RX9 & & & & & & & & & & & & & & & \\
\hline ATP synthase epsilon chain & Q6GEX3 & & & & & & & & & & & & & & & \\
\hline ATP synthase subunit delta & Q6GEW9 & & & & & & & & & & & & & & & \\
\hline ATP synthase gamma chain & Q99SF4 & & & & & & & & & & & & & & & \\
\hline $30 \mathrm{~S}$ ribosomal protein $\mathrm{S} 1$ & Q6GGT5 & & & & & & & & & & & & & & & \\
\hline $30 \mathrm{~S}$ ribosomal protein $\mathrm{S} 10$ & Q931G5 & & & & & & & & & & & & & & & \\
\hline $30 \mathrm{~S}$ ribosomal protein $\mathrm{S} 11$ & Q6GEK8 & & & & & & & & & & & & & & & \\
\hline $30 \mathrm{~S}$ ribosomal protein $\mathrm{S} 12$ & Q6GJC3 & & & & & & & & & & & & & & & \\
\hline $30 \mathrm{~S}$ ribosomal protein $\mathrm{S} 13$ & Q6GEK7 & & & & & & & & & & & & & & & \\
\hline $30 \mathrm{~S}$ ribosomal protein $\mathrm{S} 15$ & Q99UJ9 & & & & & & & & & & & & & & & \\
\hline $30 \mathrm{~S}$ ribosomal protein $\mathrm{S} 16$ & Q6GHJ7 & & & & & & & & & & & & & & & \\
\hline $30 \mathrm{~S}$ ribosomal protein $\mathrm{S} 17$ & Q8NVB4 & & & & & & & & & & & & & & & \\
\hline $30 \mathrm{~S}$ ribosomal protein $\mathrm{S} 18$ & Q6GJV1 & & & & & & & & & & & & & & & \\
\hline $30 \mathrm{~S}$ ribosomal protein S19 & Q6GEI7 & & & & & & & & & & & & & & & \\
\hline $30 \mathrm{~S}$ ribosomal protein $\mathrm{S} 2$ & Q6GHH9 & & & & & & & & & & & & & & & \\
\hline $30 \mathrm{~S}$ ribosomal protein $\mathrm{S} 20$ & Q99TR3 & & & & & & & & & & & & & & & \\
\hline $30 \mathrm{~S}$ ribosomal protein $\mathrm{S} 21$ & Q6GGC5 & & & & & & & & & & & & & & & \\
\hline $30 \mathrm{~S}$ ribosomal protein $\mathrm{S} 3$ & Q6GEI9 & & & & & & & & & & & & & & & \\
\hline 30 S ribosomal protein $\mathrm{S} 4$ & Q6GFY8 & & & & & & & & & & & & & & & \\
\hline $30 \mathrm{~S}$ ribosomal protein S5 & Q6GEK0 & & & & & & & & & & & & & & & \\
\hline $30 \mathrm{~S}$ ribosomal protein $\mathrm{S} 6$ & Q6GJV3 & & & & & & & & & & & & & & & \\
\hline $30 \mathrm{~S}$ ribosomal protein $\mathrm{S} 7$ & Q6GJC2 & & & & & & & & & & & & & & & \\
\hline
\end{tabular}


Table 2. Cont.

\begin{tabular}{|c|c|c|c|c|c|c|c|c|c|c|c|c|c|c|c|c|}
\hline \multirow{2}{*}{ Protein Name } & \multirow{2}{*}{ Acc. No. ${ }^{a}$} & \multicolumn{5}{|c|}{$18 \mathrm{~h}$} & \multicolumn{5}{|c|}{$42 \mathrm{~h}$} & \multicolumn{5}{|c|}{$66 \mathrm{~h}$} \\
\hline & & PS & G & HA & PG & TI & PS & G & HA & PG & TI & PS & G & HA I & PG & TI \\
\hline $30 \mathrm{~S}$ ribosomal protein $\mathrm{S} 8$ & Q6GEJ7 & & & & & & & & & & & & & & & \\
\hline $30 \mathrm{~S}$ ribosomal protein $\mathrm{S} 9$ & Q6GEL8 & & & & & & & & & & & & & & & \\
\hline 50 S ribosomal protein $\mathrm{L} 1$ & Q6GJD0 & & & & & & & & & & & & & & & \\
\hline $50 \mathrm{~S}$ ribosomal protein L10 & Q6GJC9 & & & & & & & & & & & & & & & \\
\hline 50 S ribosomal protein L11 & Q6GJD1 & & & & & & & & & & & & & & & \\
\hline $50 \mathrm{~S}$ ribosomal protein L13 & Q99S51 & & & & & & & & & & & & & & & \\
\hline $50 S$ ribosomal protein L14 & Q99S31 & & & & & & & & & & & & & & & \\
\hline $50 \mathrm{~S}$ ribosomal protein L15 & Q6GEK2 & & & & & & & & & & & & & & & \\
\hline 50 S ribosomal protein L16 & Q99S28 & & & & & & & & & & & & & & & \\
\hline 50 S ribosomal protein L17 & Q99S46 & & & & & & & & & & & & & & & \\
\hline $50 \mathrm{~S}$ ribosomal protein L18 & Q99S37 & & & & & & & & & & & & & & & \\
\hline $50 \mathrm{~S}$ ribosomal protein L2 & Q6GEI6 & & & & & & & & & & & & & & & \\
\hline $50 S$ ribosomal protein $\mathrm{L} 20$ & Q6GG27 & & & & & & & & & & & & & & & \\
\hline 50 S ribosomal protein L21 & Q99TK6 & & & & & & & & & & & & & & & \\
\hline 50 S ribosomal protein L22 & Q99S26 & & & & & & & & & & & & & & & \\
\hline $50 \mathrm{~S}$ ribosomal protein L23 & Q99S23 & & & & & & & & & & & & & & & \\
\hline 50 S ribosomal protein L24 & Q6GEJ4 & & & & & & & & & & & & & & & \\
\hline $50 \mathrm{~S}$ ribosomal protein L25 & Q99WA2 & & & & & & & & & & & & & & & \\
\hline $50 S$ ribosomal protein L27 & Q931Q3 & & & & & & & & & & & & & & & \\
\hline 50 ribosomal protein L28 & Q6GHL1 & & & & & & & & & & & & & & & \\
\hline $50 S$ ribosomal protein L29 & Q6GEJ1 & & & & & & & & & & & & & & & \\
\hline $50 \mathrm{~S}$ ribosomal protein L3 & Q6GEI3 & & & & & & & & & & & & & & & \\
\hline 50 S ribosomal protein L30 & Q6GEK1 & & & & & & & & & & & & & & & \\
\hline $50 \mathrm{~S}$ ribosomal protein L31 & Q6GEV5 & & & & & & & & & & & & & & & \\
\hline $50 \mathrm{~S}$ ribosomal protein L35 & Q6GG26 & & & & & & & & & & & & & & & \\
\hline $50 \mathrm{~S}$ ribosomal protein $\mathrm{L} 4$ & Q6GEI4 & & & & & & & & & & & & & & & \\
\hline $50 S$ ribosomal protein L5 & Q99S33 & & & & & & & & & & & & & & & \\
\hline $50 \mathrm{~S}$ ribosomal protein $\mathrm{L} 6$ & Q99S36 & & & & & & & & & & & & & & & \\
\hline $50 \mathrm{~S}$ ribosomal protein $\mathrm{L} 7 / \mathrm{L} 12$ & Q6GJC8 & & & & & & & & & & & & & & & \\
\hline 50 S ribosomal protein L9 & Q6GKT0 & & & & & & & & & & & & & & & \\
\hline Elongation factor $\mathrm{Tu}-\mathrm{EfTU}$ & Q6GJC0 & & & & & & & & & & & & & & & \\
\hline Elongation factor G-EfG & Q6GJC1 & & & & & & & & & & & & & & & \\
\hline Translation initiation factor IF-3-InfC & Q6GG25 & & & & & & & & & & & & & & & \\
\hline Translation initiation factor IF-2-InfB & Q6GHG6 & & & & & & & & & & & & & & & \\
\hline Elongation factor $\mathrm{P}-\mathrm{EfP}$ & Q6GGH0 & & & & & & & & & & & & & & & \\
\hline Glyceraldehyde-3-phosphate dehydrogenase & Q6GIL8 & & & & & & & & & & & & & & & \\
\hline Enolase-ENO & Q6GIL4 & & & & & & & & & & & & & & & \\
\hline Phosphoglycerate kinase-PGK & Q6GIL7 & & & & & & & & & & & & & & & \\
\hline Pyruvate kinase-PYK & Q6GG09 & & & & & & & & & & & & & & & \\
\hline Fructose-bisphosphate aldolase class 1-FBA & Q6GDJ7 & & & & & & & & & & & & & & & \\
\hline Pyruvate dehydrogenase E1-PDHB & Q6GHZ1 & & & & & & & & & & & & & & & \\
\hline Triosephosphate isomerase-TPI & Q6GIL6 & & & & & & & & & & & & & & & \\
\hline $\begin{array}{c}\text { ATP-dependent } \\
\text { 6-phosphofructokinase-PFK }\end{array}$ & Q6GG08 & & & & & & & & & & & & & & & \\
\hline 2,3-phosphoglycerate mutase-PPGM & Q6GE17 & & & & & & & & & & & & & & & \\
\hline Aconitase A-AcnA & Q6GH55 & & & & & & & & & & & & & & & \\
\hline L-lactate dehydrogenase 1-L-LDH & Q6GK73 & & & & & & & & & & & & & & & \\
\hline D-lactate dehydrogenase-D-LDH & Q6GDS2 & & & & & & & & & & & & & & & \\
\hline Alkaline shock protein 23-Asp23 & Q6GEP7 & & & & & & & & & & & & & & & \\
\hline Alcohol dehydrogenase-ADH & Q99W07 & & & & & & & & & & & & & & & \\
\hline Trigger factor-Tf & Q6GG30 & & & & & & & & & & & & & & & \\
\hline DNA-directed RNA polymerase-RpoB & Q6GJC5 & & & & & & & & & & & & & & & \\
\hline Alkyl hydroperoxide reductase-AhpC & Q6GJR7 & & & & & & & & & & & & & & & \\
\hline Alkyl hydroperoxide reductase $-\mathrm{AhpF}$ & Q6GJR8 & & & & & & & & & & & & & & & \\
\hline Chaperone protein - GroEL & Q6GF43 & & & & & & & & & & & & & & & \\
\hline Chaperone protein-DnaK & Q6GGC0 & & & & & & & & & & & & & & & \\
\hline Chaperone protein-DnaJ & Q6GGC1 & & & & & & & & & & & & & & & \\
\hline $10 \mathrm{kDa}$ chaperonin & Q6GF42 & & & & & & & & & & & & & & & \\
\hline Universal stress protein (SAV1710)-Usp & Q99TF3 & & & & & & & & & & & & & & & \\
\hline Superoxide dismutase $[\mathrm{Mn} / \mathrm{Fe}] 1$-SodA & Q6GGE6 & & & & & & & & & & & & & & & \\
\hline DNA mismatch repair protein-MutL & Q93T05 & & & & & & & & & & & & & & & \\
\hline Thermonuclease & Q5HHM4 & & & & & & & & & & & & & & & \\
\hline Glutamine synthetase & Q6GHC6 & & & & & & & & & & & & & & & \\
\hline
\end{tabular}

Color gradient from red to green is used to indicate decreasing intensity values. $4.0\left(\mathrm{LFQ}_{\log 10}\right) 9.0$ a Acc. No., accession numbers were retrieved from the UniProt protein database. In red are proteins involved in adherence and/or adherent growth (biofilm formation), and in blue are adhesive moonlighters. 
A high number of different virulence factors and factors conferring increased resistance to one or several antibiotics were also detected (Table 2). From these, gamma-hemolysin component B (HlgB), leukocidin-like proteins (Luk1/2), IgG-binding proteins (Sbi and Spa) and immunodominant antigens (IsaA and IsaB) were among the high abundant proteins in all materials at each time point. Several regulatory proteins were present in one or several of the materials already in young biofilms-among these, the relative abundance of CcpA, CodY, SarR, SaeR, Rot, MsrR, Rex and VraR increased over time, reaching the highest level at the $66 \mathrm{~h}$ time point. Enzymes involved in maintaining the cellular redox state (e.g., peptide methionine sulfoxide reductase (MsrB)) were either present or absent at $18 \mathrm{~h}$ in biofilms but could be detected with higher identification scores in all biofilms at the 42 and $66 \mathrm{~h}$ time points (Tables S1 and S2).

\subsection{Greatest Time-Dependent Variations Were Observed for TI- and HA-Associated Surfaceomes}

Comparing the number of uniquely identified proteins at different time points of growth revealed the greatest differences in TI- and HA-associated surfaceomes (Figure S3). These surfaceomes displayed a relatively high number of specific proteins at $66 \mathrm{~h}$ (HA, 74 proteins; TI, 169 proteins) and proteins shared by these two matrices at the 42 and $66 \mathrm{~h}$ time points (HA, 142 proteins; TI, 164 proteins) could not be identified in other biofilm matrices. Of note, at the $18 \mathrm{~h}$ time point, TI-associated biofilm cell surfaces were devoid of several proteins that were identified from other biofilms at this time point.

The classically secreted cell wall/membrane-anchored adhesins were either present or absent in one or several of the investigated biofilms at the $18 \mathrm{~h}$ time point (Table 2). These included the fibronectin (FnBPA) and fibrinogen binding proteins (FbnBP). For instance, FnBPA was not detected in PS, HA or TI biofilms, while HA biofilms lacked the FbnBP adhesion at this growth stage $(18 \mathrm{~h})$. The bone sialoprotein-binding protein (Bbp) was not present in $\mathrm{G}$ and TI biofilms (18 h), while elastin binding proteins $\mathrm{S}$ (EbpS) was detected only in PS and G biofilms. The clumping factors A and B (ClfA, ClfB) were also differently abundant on the tested materials at the $18 \mathrm{~h}$ time point: ClfA was specific to PS and PG biofilms, while $\mathrm{ClfB}$ was detected on every material except on TI. On the other hand, adhesins that were not detected at the $18 \mathrm{~h}$ time point (or detected with lower abundances) could be identified with reasonably high identification scores at the later time points of growth (42- and/or $66 \mathrm{~h}$ ). Such proteins included Bbp, FbnBP and the clumping factors ClfA and ClfB. In addition, FnBPA was not identified in any biofilm surfaceomes at the later time point $(66 \mathrm{~h})$. Glutamine synthetase, a potential moonlighting adhesin, was specifically identified only in TI biofilms at each time point of growth.

\subsection{Antibiotic Susceptibility Depends on the Composition of the Biofilm Surfaceome}

Based on the observed biofilm characteristics (number of cells, PNAG and protein content) the HA- and TI-associated biofilms were further tested with different antibiotics. To this end, 18 and $66 \mathrm{~h}$ biofilms were exposed to four different antimicrobial (vancomycin, penicillin $\mathrm{G}$, doxycycline, levofloxacin) agents for 2 or $24 \mathrm{~h}$. As shown in Figure 7 the viable cell counts (CFUs) decreased in a statistically significant manner $(p<0.05$ and $p<0.001)$ in all cases with the 24-h-long exposure when compared to the TSB-treated control coupons containing biofilm cells. A comparison of the used materials indicated that the 66-h-old biofilms on HA exposed to antibiotics for $2 \mathrm{~h}$ were more susceptible than biofilms on TI in all of the cases (Table 3). In general, biofilms formed on HA seemed to be more susceptible than in TI to antibiotics in most of the cases (in eight out of 11). When taking the biofilm age-related differences into account, the 66-h-old biofilms were found more susceptible than the 18-h-old biofilms in three out of 10 cases. In most of the cases (in seven out of 10), the younger biofilms (18 h) were more susceptible than the older $(66 \mathrm{~h})$ biofilms. Comparing the antibiotic treatment times indicated that increasing the exposure time from 2 to $24 \mathrm{~h}$ resulted in reduced chemotolerance in each biofilm age- and material-combination. From the tested antibiotics, levofloxacin at a final concentration of $90 \mu \mathrm{M}$ was found as the most efficient in reducing the viable colonies from biofilms formed on both materials. The most efficient antibiotic treatment was obtained with 18-h-old biofilms exposed to levofloxacin for $24 \mathrm{~h}$. 

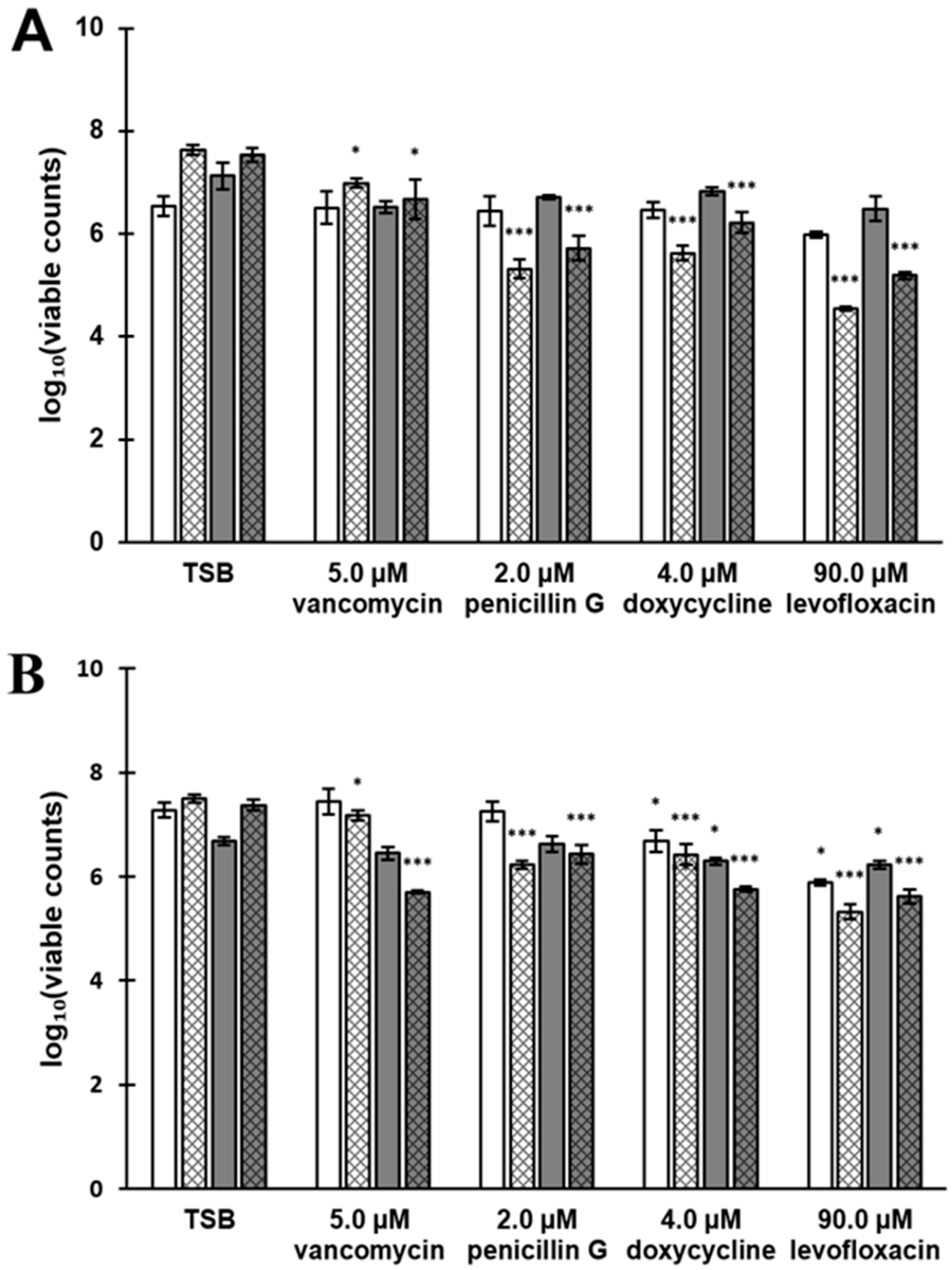

Figure 7. The chemotolerance of 18- and 66-h-old S. aureus ATCC 25923 biofilms formed on hydroxyapatite, HA (A) and titanium, TI (B) and exposed to several antibiotics for 2 or $24 \mathrm{~h}$. The results are expressed as $\log _{10}$ values of CFU. $\left(\mathrm{mL} \cdot \mathrm{cm}^{2}\right)^{-1}$. Plain white and dark grey bars illustrate 18 - and 66 -h-old biofilms (respectively) with 2-h-long antibiotic exposure, while striped white and dark grey bars illustrate 18and 66-h-old biofilms (respectively) with 24-h-long antibiotic exposure. The results of antibiotic-treated biofilms were compared to TSB-treated biofilms. The statistical analysis was performed by using unpaired t-tests with Welch's correction. ${ }^{*} p<0.05$ and ${ }^{* * *} p<0.001$ were considered statistically significant and highly significant, respectively. Error bars denote the standard error of the mean (SEM) $(n=2)$.

A combination treatment of trypsin and levofloxacin on 18- and 66-h-old biofilms formed on HA was tested. For this purpose, biofilms were first treated with trypsin $\left(51.9 \mathrm{ng} \cdot \mu \mathrm{L}^{-1}\right)$ followed by a $90 \mu \mathrm{M}$ levofloxacin treatment. Comparison of the results with the two controls (biofilms treated with TSB or $100 \mathrm{mM}$ TEAB followed by $90 \mu \mathrm{M}$ levofloxacin) revealed that the trypsin treatment alone did not benefit biofilm eradication (Figure 8). Statistically highly significant differences $(p<0.001)$ were only 
acquired when biofilms were treated with trypsin and levofloxacin in comparison with the TSB-treated biofilms. Additionally, there was no difference between the trypsin- and levofloxacin-treated 18- and 66-h-old biofilms, indicating that the protein-dependent matrix network was already well-established at the $18 \mathrm{~h}$ time point.

Table 3. The chemotolerance of S. aureus ATCC 25923 as quantified using the log reduction of viable counts. The 18-h- and 66-h-old biofilms were formed on hydroxyapatite (HA) and titanium (TI), and exposed to penicillin $\mathrm{G}$, levofloxacin, doxycycline and vancomycin.

\begin{tabular}{|c|c|c|c|c|c|c|}
\hline Biofilm Age & $\begin{array}{l}\text { Biofilm } \\
\text { Formed on }\end{array}$ & $\begin{array}{l}\text { Exposure } \\
\text { Time }\end{array}$ & $\begin{array}{c}\text { Penicillin G } \\
(2.0 \mu \mathrm{M})^{\mathrm{a}}\end{array}$ & $\begin{array}{l}\text { Levofloxacin } \\
(90.0 \mu \mathrm{M})^{\mathrm{a}}\end{array}$ & $\begin{array}{l}\text { Doxycycline } \\
(4.0 \mu \mathrm{M})^{\mathrm{a}}\end{array}$ & $\begin{array}{c}\text { Vancomycin } \\
(5.0 \mu \mathrm{M})^{\mathrm{a}}\end{array}$ \\
\hline $18 \mathrm{~h}$ & HA & $2 \mathrm{~h}$ & $0.10 \pm 0.28$ & $0.56 \pm 0.06$ & $0.08 \pm 0.15$ & $0.03 \pm 0.31$ \\
\hline $18 \mathrm{~h}$ & TI & $2 \mathrm{~h}$ & $0.01 \pm 0.19$ & $\begin{array}{c}1.39 \pm 0.05 \\
* * *, \ddagger \ddagger \ddagger\end{array}$ & $\begin{array}{c}0.59 \pm 0.21 \\
* \neq \\
* \neq\end{array}$ & $-0.17 \pm 0.25$ \\
\hline $18 \mathrm{~h}$ & HA & $24 \mathrm{~h}$ & $\begin{array}{r}2.32 \pm 0.18 \\
* * *, \ddagger \ddagger \ddagger \Omega\end{array}$ & $\begin{array}{c}3.09 \pm 0.04 \\
* * *, \neq \ddagger \ddagger, \Omega \Omega \Omega\end{array}$ & $\begin{array}{l}2.00 \pm 0.14 \\
* \neq, \Omega \Omega \Omega \\
\end{array}$ & $\begin{array}{c}0.65 \pm 0.09 \\
\Omega\end{array}$ \\
\hline $18 \mathrm{~h}$ & $\mathrm{TI}$ & $24 \mathrm{~h}$ & $\begin{array}{c}1.28 \pm 0.08 \\
\ddagger\end{array}$ & $\begin{array}{c}2.18 \pm 0.15 \\
\ddagger \ddagger \ddagger, \Omega \Omega \Omega\end{array}$ & $\begin{array}{c}1.08 \pm 0.20 \\
\Omega\end{array}$ & $0.33 \pm 0.09$ \\
\hline $66 \mathrm{~h}$ & HA & $2 \mathrm{~h}$ & $\begin{array}{c}0.42 \pm 0.04 \\
*\end{array}$ & $\begin{array}{c}0.64 \pm 0.24 \\
*, \ddagger\end{array}$ & $0.31 \pm 0.08$ & $\begin{array}{c}0.61 \pm 0.11 \\
*, \ddagger\end{array}$ \\
\hline $66 \mathrm{~h}$ & TI & $2 \mathrm{~h}$ & $0.07 \pm 0.15$ & $0.46 \pm 0.08$ & $0.39 \pm 0.06$ & $0.24 \pm 0.12$ \\
\hline $66 \mathrm{~h}$ & HA & $24 \mathrm{~h}$ & $\begin{array}{c}1.82 \pm 0.24 \\
*, \Omega \Omega \Omega\end{array}$ & $\begin{array}{c}2.35 \pm 0.07 \\
\quad * * *, \Omega\end{array}$ & $\begin{array}{c}1.32 \pm 0.20 \\
\Omega\end{array}$ & $0.88 \pm 0.38$ \\
\hline $66 \mathrm{~h}$ & TI & $24 \mathrm{~h}$ & $\begin{array}{c}0.94 \pm 0.18 \\
\Omega\end{array}$ & $\begin{array}{c}1.76 \pm 0.14 \\
\Omega \Omega \Omega\end{array}$ & $\begin{array}{l}1.62 \pm 0.04 \\
* \neq, \Omega \Omega \Omega\end{array}$ & $\begin{array}{c}1.67 \pm 0.03 \\
\Omega\end{array}$ \\
\hline
\end{tabular}

${ }^{\text {a }}$ The numbers refer to $\log \mathrm{R}$ values $( \pm \mathrm{SEM})$ indicating the difference between antibiotic- and medium-treated coupons. ${ }^{*}, p<0.05$ and ${ }^{* * *}, p<0.001$; differences between HA and TI, when the biofilm age and exposure time are the same. $\ddagger, p<0.05$ and $\ddagger \ddagger \ddagger, p<0.001$; differences between the 18- and 66-h-old biofilms when the exposure times and the materials are same. $\Omega, p<0.05$ and $\Omega \Omega \Omega, p<0.001$; differences between exposure times ( $2 \mathrm{~h}$ and $24 \mathrm{~h}$ ) when the biofilm age and the materials are the same. The statistical analyses were performed using unpaired t-tests with Welch's correction.

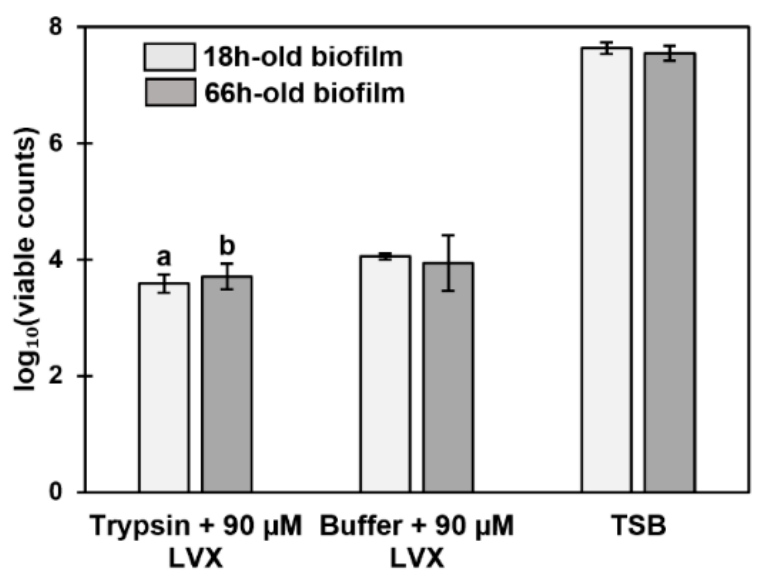

Figure 8. Viability of 18- and 66-h-old S. aureus ATCC 25923 biofilms treated with trypsin and $90 \mu \mathrm{M}$ levofloxacin (LVX), triethylammonium bicarbonate buffer (TEAB) (trypsin buffer) and $90 \mu \mathrm{M}$ levofloxacin or tryptic soy broth (TSB). The number of viable cells is expressed as $\log _{10}$ values of CFU $\left(\mathrm{mL} \cdot \mathrm{cm}^{2}\right)^{-1}$. The statistical analysis was performed using unpaired $t$-tests with Welch's correction. Highly significant change in viability $(p<0.001)$ compared to (a) TSB at $18 \mathrm{~h}$ time point and (b) TSB at $66 \mathrm{~h}$ time point. Error bars denote the standard error of the mean (SEM) $(n=2)$. 


\section{Discussion}

It is known that biofilm formation of S. aureus depends, among other factors, on the functional characteristics of the indwelling medical device and the specific surface components of the bacterium. However, many biofilm studies have traditionally utilized PS-based surface materials as the substrate for promoting adherent/biofilm growth. The biggest drawback of such studies is that the obtained results are not directly applicable to other clinically relevant substrate materials. In addition, instead of systematic studies focusing on the biofilm substrates or the biofilm matrix components, the majority of the studies have investigated the role of the individual materials or specific surface-anchored components of the adhering S. aureus. The present study aimed at filling this gap in knowledge by exploring structural features of five clinically pertinent materials and complementing the findings with in-depth surfaceomics of S. aureus ATCC 25923 biofilms growing on those materials.

\subsection{Structural Features and the Impact of PNAG on Biofilm Growth}

The surface analyses of the tested substrate materials revealed considerable differences in roughness, which, however, did not correlate with the biofilm formation efficiency. This suggests that other physicochemical factors (such as surface charge and surface energy) might have played a role in the biofilm-substrate interactions and could explain the material-dependent changes in the number of exopolysaccharides (PNAG fraction) and protein. poly- $N$-acetyl- $\beta$-(1-6)-glucosamine (PNAG; also referred to as polysaccharide intercellular adhesin (PIA)) is a major exopolysaccharide in the Staphylococcus aureus biofilm matrix. It is partially deacetylated, and its synthesis is mediated by the icaADBC locus $[64,65]$. Biofilms on PS and HA materials had the highest amount of PNAG at the $18 \mathrm{~h}$ time point, but this content was reducing over time in all materials, with the deepest drop in TI biofilms. In contrast, the protein amount was increasing towards the end of the growth. The most significant increase in protein amount was detected with $\mathrm{G}$ and HA biofilms, while the highest elevation in the number of proteins was detected with TI and HA biofilms. These findings suggest that PNAG has a more important role than proteins in coordinating the adherence of the cells in young biofilms $(18 \mathrm{~h})$ on PS and HA. In contrast, the protein role would switch to be more crucial at the later stages of biofilm formation (contributing to material-specific adherence and/or maintaining biofilm integrity/stability). PNAG has a net positive charge, which, besides promoting intercellular interactions by binding to the negatively charged surfaces of neighboring cells, might additionally have stimulated the adherence to negatively charged surfaces (such as those provided by the hydrophilic PS). Shifts in extracellular $\mathrm{pH}$ due to metabolic fluctuations may have also affected the PNAG content, as $\mathrm{pH}$ has been shown to control the EPS stability and thereby the mechanical properties of the S. aureus SH1000 biofilm [66]. PNAG is known to affect the attachment of staphylococcal biofilms, pathogenesis [67], resistance to phagocytosis, polymorphonuclear leucocytes [68,69] and antibiotic tolerance [70]. We suggest that among the materials studied here, PS and HA provide the best support for PNAG-stimulated biofilm growth.

\subsection{The Accessory and Core Surfaceomes of the S. aureus ATCC 25923 Biofilms}

Greatest variations in surfaceomes were detected for TI-, HA- and G-associated biofilms already at the $18 \mathrm{~h}$ time point. Virulence factors such as hemolysin HlgB and EsxA (a chaperone and/or an adaptor protein, which interacts with host receptor proteins and interferes with host cell apoptotic pathways) [71,72], were found moderately abundant in all biofilms at the 42 and $66 \mathrm{~h}$ time points. Staphopain A (SspP), detected here in all biofilms (except on HA, at $18 \mathrm{~h}$ ), has been proposed to increase bacterial persistence through, e.g., degrading the antimicrobial human peptide LL-37 [73]. Immunodominant antigens IsaA and IsaB were dominating proteins in all biofilm samples. IsaA has been proposed to have autolytic activity [74], while elevated IsaB-levels promote the virulence and persistence of MRSA [75]. Increased abundance of IsaA has also been reported for Staphylococcus epidermidis biofilms formed on TI [76], implying that this antigen could have mediated S. aureus biofilm 
formation on the selected materials in our study. Bifunctional autolysin (AtlA), identified on all materials at every time point, has been reported to be responsible for initial attachment in biofilm formation, bacterial cell wall degradation and cell separation during cell division [46,77]. In addition, this autolysin is also reported with a potential role in FnBP-mediated biofilm maturation [78]. Our findings suggest that FnBPA could be important in earlier stages of biofilm formation (in young biofilms, at the $18 \mathrm{~h}$ time point), whereas the abundance of FbnBP in older biofilms implies this adhesin might have a more prominent role in biofilm maturation.

Staphylococcal secretory antigen (SsaA) was one of the most abundant secreted antigens detected in all biofilm samples (except on TI); this immunodominant antigen is suggested to be involved in biofilm growth and biofilm-related infections [79,80]. The immunoglobulin-binding protein A (Spa), identified on all materials at every time point, has been shown to be in a pivotal role in biofilm formation [81]. Other potential surface adhesins, such as Ser-Asp repeat-containing protein C (SdrC), ClfA, ClfB, Bbp and EbpS detected here in initial stages of biofilm growth on one or several of the tested materials, could also play a role in promoting initial adherence to the tested materials. Glutamine synthetase, with an ability to bind fibronectin, laminin, collagen I and plasminogen [82], was specifically identified only in TI-associated biofilms, implying that biofilms formed on this substrate could interfere with the host immune defense system.

\subsection{The Surface-Associated Moonlighters Dominate in All Studied Biofilms}

The cytoplasmic proteins with predicted multitasking functions [82,83] formed the biggest group among all identified proteins, independent of the biofilm substrate used. The presence of cytoplasmic proteins in the extracellular milieu has been widely explained with cell lysis/leakage. However, this interpretation seems to be too simple, since several lines of evidence imply the existence of a yet unknown mechanism controlling cytoplasmic protein excretion. For example, it has been noted that cytoplasmic protein excretion is increased when the autolysins are up-regulated and peptidoglycan cross-linking is decreased [84]. Cell lysis in S. aureus biofilms has been shown to depend on the presence of the major autolysin Atl, the holin/antiholin system CidABC and LrgAB [78,85-87]. Atl has been shown to be strongly upregulated in moderately aged S. aureus biofilms, which resulted in strong lysis and accumulation of intracellular proteins in the biofilm matrix [47].

Thus, besides the conventional autolysin activity, AtlA can also control the excretion of cytoplasmic proteins (e.g., EfTU) to the cell surface; a process that is not random, but suggested to involve selection based on certain sequence motifs (e.g., $\alpha$-helices) [84,87-89]. The Atl-mediated protein export could also occur in vivo in $S$. aureus, indicated by recent results in the post-arthroplasty joint infection model (hypodermic stainless-steel rod) where higher levels of cytoplasmic proteins were found, compared to the classical surface adhesins or other classically secreted proteins [48]. From the cytoplasmic proteins, GaPDH has been detected with increased abundances in S. epidermidis biofilms formed on TI [76], indicating that this moonlighter could be important for biofilm formation or stability of the formed biofilms. Besides their conventional roles in cytoplasm, the cytoplasmic proteins are reported to have also adhesive (to plasminogen, laminin, Caco-2-cell, mucin, EPS-derived mannan or rhamnose), immunomodulatory and/or biofilm formation stimulating functions [90-94].

Here, the r-protein moonlighters, bearing a high net positive charge with high affinity towards anionic cell wall components (eDNA and anionic metabolites), formed the biggest group of the identified moonlighting proteins. This is supported by [47], showing that r-proteins and several secreted virulence proteins (both having a strong positive charge) are embedded in the acidic S. aureus biofilm matrix. Acidic conditions are generated by the release of fermentation end-products as a response to oxygen limitation in the biofilms. In that study, the r-proteins were suggested to contribute to the $\mathrm{pH}$-dependent stability of the biofilms. The r-proteins are classically involved in translation, but after associating with cell surfaces, they could also function as a defensive mechanism in response to external challenges originating from the host immune system, antibiotics or other challenges, as previously reported by [95]. 
This has been supported by a recent proteomic study reporting that the production of r-proteins is increased in response to an antibacterial agent, quinolonyl-oxazolidinone [96].

Our study also indicated the presence of several regulatory proteins normally acting in intracellular milieu by coordinating biofilm growth, virulence and/or drug resistance [97] at biofilm cell surfaces. S. aureus is also reported to use membrane vesicles (MVs) to transfer regulators, virulence factors and drug resistance enzymes in a protected and concentrated manner [98-102]. Regulator proteins SarR, SarS and Rot, as well as r-proteins, malate:quinone oxidoreductase 2 (MQO2), hemolysins, leukocidins, certain moonlighters (EfG, EfTU, chaperone protein DnaJ, Usp, PYK, ENO, PDHB, ATP synthase subunit beta), foldase protein A (PrsA) and penicillin-binding protein were previously identified from MVs isolated from S. aureus 06ST1048 [101]. Notably, leukocidins have been shown to be efficiently produced also during chronic infection in vivo [48], which further suggests that $S$. aureus can actively modulate the host immune system even protected within the biofilm. Thus, it can be hypothesized that these virulence factors are sorted into MVs for protected export, together with necessary moonlighters, aiming at maintaining the cohesion and viability of the biofilm community in vivo.

\subsection{Older Biofilms Are Not Always More Tolerant Than Younger Biofilms}

Our findings suggested that PS, G and PG could provoke protein-dependent antibiotic resistance, as the enzymes lysostaphin resistance protein A (LyrA) and methicillin resistance-associated FemA/B and FmtA [103-105] were detected in PS, PG and/or G biofilms already at the $18 \mathrm{~h}$ time point, implying that biofilms on other materials may be more susceptible to certain antibiotics. In our study, chemotolerance tests were executed with different antibiotics covering a broad spectrum of mechanisms of action: vancomycin (glycopeptide: inhibits cell wall synthesis by forming complexes with peptidoglycan precursors [106]), penicillin G (B-lactam: inhibits cell wall synthesis via preventing peptidoglycan polymerization [107]), doxycycline (tetracycline: inhibits protein synthesis by binding to the $30 \mathrm{~S}$ subunit of the bacterial ribosome [108]) and levofloxacin (fluoroquinolone: inhibits bacterial DNA gyrase and topoisomerase IV in Gram-negative and Gram-positive bacteria, respectively, and blocking DNA replication [109]). Furthermore, levofloxacin, vancomycin and doxycycline are used as a part of treatment regimen in managing prosthetic joint infections caused by Staphylococcus spp. Usually, vancomycin is administered intravenously for the first two weeks after the surgical therapy (if oxacillin-, methicillin- or rifampicin-resistance has been observed), while doxycycline and levofloxacin are given per oral as a continuation therapy (a total duration of antibiotic treatment is 12 weeks) [110]. Our results were in accordance with the results obtained by [111], where several antibiotics were tested against Staphylococcus aureus ATCC 25923. Therein, levofloxacin was the most effective, followed by doxycycline, penicillin $\mathrm{G}$ and vancomycin (least active). In our study, levofloxacin was the most effective, while the second most active was penicillin $G$ or doxycycline depending on the biofilm age, used substrate material or exposure time of the antibiotic. Least active was vancomycin, as well. Furthermore, in another study, doxycycline displayed higher activity than vancomycin against different Staphylococcus aureus clinical isolates [112].

The results also revealed that in many cases, biofilms formed on HA were more susceptible to antibiotics than biofilms on TI. Unexpectedly, the $66 \mathrm{~h}$ biofilms were not always more tolerant than those grown for $18 \mathrm{~h}$, which may suggest that other surface factors, such as the r-protein moonlighters or other moonlighting proteins could have contributed to the observed phenotypes.

\subsection{Several Biofilm Surfaceome Proteins Are Important for Successful Infection}

Hemolysins, leukocidins, stress proteins (AhpC/F, Usp, SodA), resistance (FmtA), chaperones (ClpL, ClpC, ClpB, DnaK and GroEL) and response regulators (VraR, CodY and CcpA) identified here already at 18-h-old biofilms were recently suggested to be involved in host-pathogen interactions in vivo [113]. Several of these proteins were also identified as secreted and/or matrix-associated proteins in an implant-associated biofilm in vivo infection model [48]. In addition, the Clp family proteins are reported to be important for biofilm formation and virulence [114]. The appearance of 
$\mathrm{ClpP}$ at the cell surface is interesting, as the enzyme can be activated by an acyldepsipeptide antibiotic into a non-specific protease capable of killing S. aureus persisters [115].

\section{Conclusions}

The present study indicated the importance of PNAG and dedicated cell wall/membrane-anchored proteins during the initial stages of biofilm formation. The recycling of cytoplasmic proteins as moonlighting components could benefit biofilm population by increasing the integrity, stability and drug resistance of the cells. As the development of the protein matrix was slowest on HA and TI, our study proposes that these substrates could provide a good starting point for generating new clinical materials with enhanced anti-biofilm features. Prior to this, as biofilms formed on HA were found to reach sufficient maturity already at the $18 \mathrm{~h}$ time point, in-depth surfaceome analysis on this material should be investigated also at earlier time points. Classical surface proteins have been considered as the most attractive targets in drug design against bacterial pathogens. However, this research should be expanded to also include non-classical moonlighters, as many of these can contribute to virulence and drug tolerance. Thus, understanding mechanisms coordinating the moonlighting activity would not only provide fundamental insights into bacterial gene regulation, but it may also shed better insight into new strategies aimed at designing novel anti-biofilm agents/materials.

Supplementary Materials: The following are available online at http://www.mdpi.com/2076-2607/7/12/584/s1. Figure S1: The viability of S. aureus ATCC 25923 biofilm cells treated with trypsin or $100 \mathrm{mM}$ TEAB buffer (control). Figure S2: Length-scale dependent roughness of the materials. Figure S3: Venn diagrams indicating the number of proteins specific and common to the indicated materials at different time points of growth. Table S1: The MaxQuant output-file showing the identified proteins after searching the MS/MS raw data against the UniProt Staphylococcus protein database. Table S2: The identified matrix-associated surfaceomes from S. aureus ATCC 25923 biofilms formed on different substrates at indicated time points.

Author Contributions: Design of the experiments, A.K.H. and A.F.; performance of the biofilm experiments, A.K.H.; LC-MS/MS analyses, T.A.N.; proteomic data analyses, A.K.H., I.M. and K.S.; AFM pictures and surface roughness analyses, P.I; writing, A.K.H., A.F. and K.S. All the authors reviewed and commented on the manuscript.

Funding: This research was funded by The Finnish Pharmaceutical Society, Doctoral Programme in Drug Research (DPDR), Jane and Aatos Erkko Foundation, The Academy of Finland (projects 272266, 282981, 292646 and 272363) and the University of Helsinki.

Acknowledgments: The authors thank Sabina Pham and Vincent Voet for their assistance in laboratory work.

Conflicts of Interest: The authors declare no conflict of interest.

\section{References}

1. Nymer, M.; Cope, E.; Brady, R.; Shirtliff, M.E.; Leid, J.G. Immune responses to indwelling medical devices. In The Role of Biofilms in Device-Related Infections, 1st ed.; Shirtliff, M.E., Leid, J.G., Eds.; Springer: Cham, Switzerland, 2008; Volume 3, pp. 239-264.

2. Zimmerli, W. Clinical presentation and treatment of orthopaedic implant-associated infection. J. Intern. Med. 2014, 276, 111-119. [CrossRef]

3. Trampuz, A.; Zimmerli, W. Diagnosis and treatment of implant-associated septic arthritis and osteomyelitis. Curr. Infect. Dis. Rep. 2008, 10, 394-403. [CrossRef]

4. Peters, G.; Locci, R.; Pulverer, G. Adherence and growth of coagulase-negative staphylococci on surfaces of intravenous catheters. J. Infect. Dis. 1982, 146, 479-482. [CrossRef]

5. Bouza, E.; San Juan, R.; Muñoz, P.; Pascau, J.; Voss, A.; Desco, M.; Cooperative Group of the European Study Group on Nosocomial Infections (ESGNI). A European perspective on intravascular catheter-related infections: Report on the microbiology workload, aetiology and antimicrobial susceptibility (ESGNI-005 Study). Clin. Microbiol. Infect. 2004, 10, 838-842. [CrossRef]

6. Chua, J.D.; Wilkoff, B.L.; Lee, I.; Juratli, N.; Longworth, D.L.; Gordon, S.M. Diagnosis and management of infections involving implantable electrophysiologic cardiac devices. Ann. Intern. Med. 2000, 133, 604-608. [CrossRef]

7. Brand, K.G. Infection of mammary prostheses: A survey and the question of prevention. Ann. Plast. Surg. 1993, 30, 289-295. [CrossRef] 
8. Pittet, B.; Montandon, D.; Pittet, D. Infection in breast implants. Lancet Infect. Dis. 2005, 5, 94-106. [CrossRef]

9. Benito, N.; Franco, M.; Ribera, A.; Soriano, A.; Rodriguez-Pardo, D.; Sorlí, L.; Fresco, G.; Fernández-Sampedro, M.; Dolores Del Toro, M.; Guío, L.; et al. Time trends in the aetiology of prosthetic joint infections: A multicentre cohort study. Clin. Microbiol. Infect. 2016, 22, e1-e8. [CrossRef]

10. Costerton, J.W.; Lewandowski, Z.; Caldwell, D.E.; Korber, D.R.; Lappin-Scott, H.M. Microbial biofilms. Annu. Rev. Microbiol. 1995, 49, 711-745. [CrossRef]

11. Costerton, J.W.; Stewart, P.S.; Greenberg, E.P. Bacterial biofilms: A common cause of persistent infections. Science 1999, 284, 1318-1322. [CrossRef]

12. Donlan, R.M. Role of biofilms in antimicrobial resistance. ASAIO J. 2000, 46, S47-S52. [CrossRef]

13. Bjarnsholt, T.; Jensen, P.Ø.; Fiandaca, M.J.; Pedersen, J.; Hansen, C.R.; Andersen, C.B.; Pressler, T.; Givskov, M.; Høiby, N. Pseudomonas aeruginosa biofilms in the respiratory tract of cystic fibrosis patients. Pediatr. Pulmonol. 2009, 44, 547-558. [CrossRef]

14. Bjarnsholt, T.; Ciofu, O.; Molin, S.; Givskov, M.; Høiby, N. Applying insights from biofilm biology to drug development-Can a new approach be developed? Nat. Rev. Drug Discov. 2013, 12, 791-808. [CrossRef]

15. Flemming, H.C.; Wingender, J. The biofilm matrix. Nat. Rev. Microbiol. 2010, 8, 623-633. [CrossRef]

16. Massey, R.C.; Kantzanou, M.N.; Fowler, T.; Day, N.P.; Schofield, K.; Wann, E.R.; Berendt, A.R.; Höök, M.; Peacock, S.J. Fibronectin-Binding protein A of Staphylococcus aureus has multiple, substituting, binding regions that mediate adherence to fibronectin and invasion of endothelial cells. Cell. Microbiol. 2001, 3, 839-851. [CrossRef]

17. Foster, T.J. The remarkably multifunctional fibronectin binding proteins of Staphylococcus aureus. Eur. J. Clin. Microbiol. Infect. Dis. 2016, 35, 1923-1931. [CrossRef]

18. Høiby, N.; Bjarnsholt, T.; Moser, C.; Bassi, G.L.; Coenye, T.; Donelli, G.; Hall-Stoodley, L.; Holá, V.; Imbert, C.; Kirketerp-Møller, K.; et al. ESCMID guideline for the diagnosis and treatment of biofilm infections 2014. Clin. Microbiol. Infect. 2015, 21, 1-25. [CrossRef]

19. Spellberg, B.; Lipsky, B.A. Systemic antibiotic therapy for chronic osteomyelitis in adults. Clin. Infect. Dis. 2012, 54, 393-407. [CrossRef]

20. Gergely, I.; Zazgyva, A.; Man, A.; Zuh, S.G.; Pop, T.S. The in vitro antibacterial effect of S53P4 bioactive glass and gentamicin impregnated polymethylmethacrylate beads. Acta Microbiol. Immunol. Hung. 2014, 61, 145-160. [CrossRef]

21. Drago, L.; Vassena, C.; Fenu, S.; De Vecchi, E.; Signori, V.; De Francesco, R.; Romanò, C.L. In vitro antibiofilm activity of bioactive glass S53P4. Future Microbiol. 2014, 9, 593-601. [CrossRef]

22. Drago, L.; Boot, W.; Dimas, K.; Malizos, K.; Hänsch, G.M.; Stuyck, J.; Gawlitta, D.; Romanò, C.L. Does implant coating with antibacterial-loaded hydrogel reduce bacterial colonization and biofilm formation in vitro? Clin. Orthop. Relat. Res. 2014, 472, 3311-3323. [CrossRef]

23. Braem, A.; De Cremer, K.; Delattin, N.; De Brucker, K.; Neirinck, B.; Vandamme, K.; Martens, J.A.; Michiels, J.; Vleugels, J.; Cammue, B.P.; et al. Novel anti-infective implant substrates: Controlled release of antibiofilm compounds from mesoporous silica-containing macroporous titanium. Colloids Surf. B Biointerfaces 2015, 126, 481-488. [CrossRef]

24. Jennings, J.A.; Carpenter, D.P.; Troxel, K.S.; Beenken, K.E.; Smeltzer, M.S.; Courtney, H.S.; Haggard, W.O. Novel antibiotic-loaded point-of-care implant coating inhibits biofilm. Clin. Orthop. Relat. Res. 2015, 473, 2270-2282. [CrossRef]

25. Shukla, V.; Bhathena, Z. Sustained release of a purified tannin component of Terminalia chebula from a titanium implant surface prevents biofilm formation by Staphylococcus aureus. Appl. Biochem. Biotechnol. 2015, 175, 3542-3556. [CrossRef]

26. Tran, N.; Kelley, M.N.; Tran, P.A.; Garcia, D.R.; Jarrell, J.D.; Hayda, R.A.; Born, C.T. Silver doped titanium oxide-PDMS hybrid coating inhibits Staphylococcus aureus and Staphylococcus epidermidis growth on PEEK. Mater. Sci. Eng. C Mater. Biol. Appl. 2015, 49, 201-209. [CrossRef]

27. Aamdal Scheie, A.; Chamgordani, E.J.; Naemi, A.O.; Hansen, F.K.; Benneche, T. Staphylococcus epidermidis biofilm on implant material is reduced by a covalently linked thiophenone. J. Appl. Microbiol. 2016, 121, 547-553. [CrossRef]

28. Hiltunen, A.K.; Skogman, M.E.; Rosenqvist, K.; Juvonen, H.; Ihalainen, P.; Peltonen, J.; Juppo, A.; Fallarero, A. Bioactive glass combined with bisphosphonates provides protection against biofilms formed by the periodontal pathogen Aggregatibacter actinomycetemcomitans. Int. J. Pharm. 2016, 501, 211-220. [CrossRef] 
29. Hiltunen, A.K.; Vuorela, P.M.; Fallarero, A. Bisphosphonates offer protection against prosthetic joint infections caused by Staphylococcus aureus and Staphylococcus epidermidis biofilms. J. Drug Deliv. Sci. Technol. 2017, 40, 136-141. [CrossRef]

30. Liu, X.; Tian, A.; You, J.; Zhang, H.; Wu, L.; Bai, X.; Lei, Z.; Shi, X.; Xue, X.; Wang, H. Antibacterial abilities and biocompatibilities of Ti-Ag alloys with nanotubular coatings. Int. J. Nanomed. 2016, 11, 5743-5755. [CrossRef]

31. Sankar, G.G.; Murthy, P.S.; Das, A.; Sathya, S.; Nankar, R.; Venugopalan, V.P.; Doble, M. Polydimethyl siloxane based nanocomposites with antibiofilm properties for biomedical applications. J. Biomed. Mater. Res. B Appl. Biomater. 2017, 105, 1075-1082. [CrossRef]

32. Zaatreh, S.; Haffner, D.; Strauß, M.; Wegner, K.; Warkentin, M.; Lurtz, C.; Zamponi, C.; Mittelmeier, W.; Kreikemeyer, B.; Willumeit-Römer, R.; et al. Fast corroding, thin magnesium coating displays antibacterial effects and low cytotoxicity. Biofouling 2017, 33, 294-305. [CrossRef]

33. Drago, L.; Bortolin, M.; De Vecchi, E.; Agrappi, S.; Weinstein, R.L.; Mattina, R.; Francetti, L. Antibiofilm activity of sandblasted and laser-modified titanium against microorganisms isolated from peri-implantitis lesions. J. Chemother. 2016, 28, 383-389. [CrossRef]

34. Sánchez, M.C.; Llama-Palacios, A.; Fernández, E.; Figuero, E.; Marín, M.J.; León, R.; Blanc, V.; Herrera, D.; Sanz, M. An in vitro biofilm model associated to dental implants: Structural and quantitative analysis of in vitro biofilm formation on different dental implant surfaces. Dent. Mater. 2014, 30, 1161-1171. [CrossRef]

35. Pita, P.P.; Rodrigues, J.A.; Ota-Tsuzuki, C.; Miato, T.F.; Zenobio, E.G.; Giro, G.; Figueiredo, L.C.; Gonçalves, C.; Gehrke, S.A.; Cassoni, A.; et al. Oral streptococci biofilm formation on different implant surface topographies. Biomed. Res. Int. 2015, 2015, 159625. [CrossRef]

36. Al-Ahmad, A.; Karygianni, L.; Schulze Wartenhorst, M.; Bächle, M.; Hellwig, E.; Follo, M.; Vach, K.; Han, J.S. Bacterial adhesion and biofilm formation on yttria-stabilized, tetragonal zirconia and titanium oral implant materials with low surface roughness-An in situ study. J. Med. Microbiol. 2016, 65, 596-604. [CrossRef]

37. De Avila, E.D.; Avila-Campos, M.J.; Vergani, C.E.; Spolidório, D.M.; Mollo Fde, A., Jr. Structural and quantitative analysis of a mature anaerobic biofilm on different implant abutment surfaces. J. Prosthet. Dent. 2016, 115, 428-436. [CrossRef]

38. Roehling, S.; Astasov-Frauenhoffer, M.; Hauser-Gerspach, I.; Braissant, O.; Woelfler, H.; Waltimo, T.; Kniha, H.; Gahlert, M. In vitro biofilm formation on titanium and zirconia implant surfaces. J. Periodontol. 2017, 88, 298-307. [CrossRef]

39. Payne, D.E.; Boles, B.R. Emerging interactions between matrix components during biofilm development. Curr. Genet. 2016, 62, 137-141. [CrossRef] [PubMed]

40. Koseki, H.; Yonekura, A.; Shida, T.; Yoda, I.; Horiuchi, H.; Morinaga, Y.; Yanagihara, K.; Sakoda, H.; Osaki, M.; Tomita, M. Early staphylococcal biofilm formation on solid orthopaedic implant materials: In vitro study. PLoS ONE 2014, 9, e107588. [CrossRef]

41. Patel, S.S.; Aruni, W.; Inceoglu, S.; Akpolat, Y.T.; Botimer, G.D.; Cheng, W.K.; Danisa, O.A. A comparison of Staphylococcus aureus biofilm formation on cobalt-chrome and titanium-alloy spinal implants. J. Clin. Neurosci. 2016, 31, 219-223. [CrossRef]

42. Foster, T.J.; Geoghegan, J.A.; Ganesh, V.K.; Höök, M. Adhesion, invasion and evasion: The many functions of the surface proteins of Staphylococcus aureus. Nat. Rev. Microbiol. 2014, 12, 49-62. [CrossRef] [PubMed]

43. Foulston, L.; Elsholz, A.K.; DeFrancesco, A.S.; Losick, R. The extracellular matrix of Staphylococcus aureus biofilms comprises cytoplasmic proteins that associate with the cell surface in response to decreasing $\mathrm{pH}$. MBio 2014, 5, e01667-14. [CrossRef] [PubMed]

44. Speziale, P.; Pietrocola, G.; Foster, T.J.; Geoghegan, J.A. Protein-Based biofilm matrices in staphylococci. Front. Cell. Infect. Microbiol. 2014, 4, 171. [CrossRef]

45. Kim, S.J.; Chang, J.; Rimal, B.; Yang, H.; Schaefer, J. Surface proteins and the formation of biofilms by Staphylococcus aureus. Biochim. Biophys. Acta Biomembr. 2018, 1860, 749-756. [CrossRef]

46. Porayath, C.; Suresh, M.K.; Biswas, R.; Nair, B.G.; Mishra, N.; Pal, S. Autolysin mediated adherence of Staphylococcus aureus with fibronectin, gelatin and heparin. Int. J. Biol. Macromol. 2018, 110, 179-184. [CrossRef]

47. Graf, A.C.; Leonard, A.; Schäuble, M.; Rieckmann, L.M.; Hoyer, J.; Maass, S.; Lalk, M.; Becher, D.; Pané-Farré, J.; Riedel, K. Virulence factors produced by Staphylococcus aureus biofilms have a moonlighting function contributing to biofilm integrity. Mol. Cell Proteom. 2019, 18, 1036-1053. [CrossRef] 
48. Lei, M.G.; Gupta, R.K.; Lee, C.Y. Proteomics of Staphylococcus aureus biofilm matrix in a rat model of orthopedic implant-associated infection. PLoS ONE 2017, 12, e0187981. [CrossRef]

49. Treangen, T.J.; Maybank, R.A.; Enke, S.; Friss, M.B.; Diviak, L.F.; Karaolis, D.K.; Koren, S.; Ondov, B.; Phillippy, A.M.; Bergman, N.H.; et al. Complete genome sequence of the quality control strain Staphylococcus aureus subsp. aureus ATCC 25923. Genome Announc. 2014, 2, e01110-14. [CrossRef]

50. Hench, L.L.; Day, D.E.; Höland, W.; Rheinberger, V.M. Glass and medicine. Int. J. Appl. Glass Sci. 2010, 1, 104-117. [CrossRef]

51. Peters, W.; Fornasier, V. Complications from injectable materials used for breast augmentation. Can. J. Plast. Surg. 2009, 17, 89-96. [CrossRef]

52. Arora, M.; Chan, E.K.; Gupta, S.; Diwan, A.D. Polymethylmethacrylate bone cements and additives: A review of the literature. World J. Orthop. 2013, 4, 67-74. [CrossRef] [PubMed]

53. Kelly, M.; Williams, R.; Aojula, A.; O’Neill, J.; Trzińscka, Z.; Grover, L.; Scott, R.A.; Peacock, A.F.; Logan, A.; Stamboulis, A.; et al. Peptide aptamers: Novel coatings for orthopaedic implants. Mater. Sci. Eng. C Mater. Biol. Appl. 2015, 54, 84-93. [CrossRef] [PubMed]

54. Skogman, M.E.; Vuorela, P.M.; Fallarero, A. Combining biofilm matrix measurements with biomass and viability assays in susceptibility assessments of antimicrobials against Staphylococcus aureus biofilms. J. Antibiot. 2012, 65, 453-459. [CrossRef] [PubMed]

55. Hiltunen, A.; Skogman, M.; Vuorela, P.M.; Fallarero, A. Exploration of microbial communities using the Thermo Scientific Varioskan LUX multimode reader and the invitrogen EVOS FL cell imaging system. Biotechniques 2017, 63, 236-237. [CrossRef]

56. Savijoki, K.; Nyman, T.A.; Kainulainen, V.; Miettinen, I.; Siljamäki, P.; Fallarero, A.; Sandholm, J.; Satokari, R.; Varmanen, P. Growth mode and carbon source impact the surfaceome dynamics of Lactobacillus rhamnosus GG. Front. Microbiol. 2019, 10, 1272. [CrossRef]

57. Espino, E.; Koskenniemi, K.; Mato-Rodriguez, L.; Nyman, T.A.; Reunanen, J.; Koponen, J.; Öhman, T.; Siljamäki, P.; Alatossava, T.; Varmanen, P.; et al. Uncovering surface-exposed antigens of Lactobacillus rhamnosus by cell shaving proteomics and two-dimensional immunoblotting. J. Proteome Res. 2015, 14, 1010-1024. [CrossRef] [PubMed]

58. Lorey, M.B.; Rossi, K.; Eklund, K.K.; Nyman, T.A.; Matikainen, S. Global characterization of protein secretion from human macrophages following non-canonical caspase- $4 / 5$ inflammasome activation. Mol. Cell. Proteom. 2017, 16, 187-199. [CrossRef]

59. Cox, J.; Mann, M. MaxQuant enables high peptide identification rates, individualized p.p.b.--Range mass accuracies and proteome-wide protein quantification. Nat. Biotechnol. 2008, 26, 1367-1372. [CrossRef]

60. Cox, J.; Neuhauser, N.; Michalski, A.; Scheltema, R.A.; Olsen, J.V.; Mann, M. Andromeda: A peptide search engine integrated into the MaxQuant environment. J. Proteome Res. 2011, 10, 1794-1805. [CrossRef]

61. Pitts, B.; Hamilton, M.A.; Zelver, N.; Stewart, P.S. A microtiter-plate screening method for biofilm disinfection and removal. J. Microbiol. Methods 2003, 54, 269-276. [CrossRef]

62. Zhang, J.H.; Chung, T.D.; Oldenburg, K.R. A simple statistical parameter for use in evaluation and validation of high throughput screening assays. J. Biomol. Screen. 1999, 4, 67-73. [CrossRef] [PubMed]

63. Bollini, S.; Herbst, J.J.; Gaughan, G.T.; Verdoorn, T.A.; Ditta, J.; Dubowchik, G.M.; Vinitsky, A. High-Throughput fluorescence polarization method for identification of FKBP12 ligands. J. Biomol. Screen. 2002, 7, 526-530. [CrossRef] [PubMed]

64. Mack, D.; Fischer, W.; Krokotsch, A.; Leopold, K.; Hartmann, R.; Egge, H.; Laufs, R. The intercellular adhesin involved in biofilm accumulation of Staphylococcus epidermidis is a linear beta-1,6-linked glucosaminoglycan: Purification and structural analysis. J. Bacteriol. 1996, 178, 175-183. [CrossRef] [PubMed]

65. Cramton, S.E.; Gerke, C.; Schnell, N.F.; Nichols, W.W.; Götz, F. The intercellular adhesion (ica) locus is present in Staphylococcus aureus and is required for biofilm formation. Infect. Immun. 1999, 67, 5427-5433.

66. Stewart, E.J.; Ganesan, M.; Younger, J.G.; Solomon, M.J. Artificial biofilms establish the role of matrix interactions in staphylococcal biofilm assembly and disassembly. Sci. Rep. 2015, 5, 13081. [CrossRef]

67. Lin, M.H.; Shu, J.C.; Lin, L.P.; Chong, K.Y.; Cheng, Y.W.; Du, J.F.; Liu, S.T. Elucidating the crucial role of poly n-acetylglucosamine from Staphylococcus aureus in cellular adhesion and pathogenesis. PLoS ONE 2015, 10, e0124216. [CrossRef] 
68. Kropec, A.; Maira-Litran, T.; Jefferson, K.K.; Grout, M.; Cramton, S.E.; Götz, F.; Goldmann, D.A.; Pier, G.B. Poly-N-Acetylglucosamine production in Staphylococcus aureus is essential for virulence in murine models of systemic infection. Infect. Immun. 2005, 73, 6868-6876. [CrossRef]

69. Vuong, C.; Voyich, J.M.; Fischer, E.R.; Braughton, K.R.; Whitney, A.R.; De Leo, F.R.; Otto, M. Polysaccharide intercellular adhesin (PIA) protects Staphylococcus epidermidis against major components of the human innate immune system. Cell. Microbiol. 2004, 6, 269-275. [CrossRef]

70. Costa, A.R.; Henriques, M.; Oliveira, R.; Azeredo, J. The role of polysaccharide intercellular adhesin (PIA) in Staphylococcus epidermidis adhesion to host tissues and subsequent antibiotic tolerance. Eur. J. Clin. Microbiol. Infect. Dis. 2009, 28, 623-629. [CrossRef]

71. Sundaramoorthy, R.; Fyfe, P.K.; Hunter, W.N. Structure of Staphylococcus aureus EsxA suggests a contribution to virulence by action as a transport chaperone and/or adaptor protein. J. Mol. Biol. 2008, 383, 603-614. [CrossRef]

72. Korea, C.G.; Balsamo, G.; Pezzicoli, A.; Merakou, C.; Tavarini, S.; Bagnoli, F.; Serruto, D.; Unnikrishnan, M. Staphylococcal Esx proteins modulate apoptosis and release of intracellular Staphylococcus aureus during infection in epithelial cells. Infect. Immun. 2014, 82, 4144-4153. [CrossRef] [PubMed]

73. Sonesson, A.; Przybyszewska, K.; Eriksson, S.; Mörgelin, M.; Kjellström, S.; Davies, J.; Potempa, J.; Schmidtchen, A. Identification of bacterial biofilm and the Staphylococcus aureus derived protease, staphopain, on the skin surface of patients with atopic dermatitis. Sci. Rep. 2017, 7, 8689. [CrossRef] [PubMed]

74. Stapleton, M.R.; Horsburgh, M.J.; Hayhurst, E.J.; Wright, L.; Jonsson, I.M.; Tarkowski, A.; Kokai-Kun, J.F.; Mond, J.J.; Foster, S.J. Characterization of IsaA and SceD, two putative lytic transglycosylases of Staphylococcus aureus. J. Bacteriol. 2007, 189, 7316-7325. [CrossRef] [PubMed]

75. Liu, P.F.; Cheng, J.S.; Sy, C.L.; Huang, W.C.; Yang, H.C.; Gallo, R.L.; Huang, C.M.; Shu, C.W. IsaB Inhibits autophagic flux to promote host transmission of methicillin-resistant Staphylococcus aureus. J. Investig. Dermatol. 2015, 135, 2714-2722. [CrossRef] [PubMed]

76. Bürgers, R.; Morsczeck, C.; Felthaus, O.; Gosau, M.; Beck, H.C.; Reichert, T.E. Induced surface proteins of Staphylococcus epidermidis adhering to titanium implant substrata. Clin. Oral Investig. 2018, 22, 2663-2668. [CrossRef]

77. Zoll, S.; Pätzold, B.; Schlag, M.; Götz, F.; Kalbacher, H.; Stehle, T. Structural basis of cell wall cleavage by a staphylococcal autolysin. PLoS Pathog. 2010, 6, e1000807. [CrossRef]

78. Houston, P.; Rowe, S.E.; Pozzi, C.; Waters, E.M.; O'Gara, J.P. Essential Role for the Major Autolysin in the Fibronectin-Binding Protein-Mediated Staphylococcus aureus Biofilm Phenotype. Infect. Immun. 2011, 79, 1153-1165. [CrossRef]

79. Lang, S.; Livesley, M.A.; Lambert, P.A.; Littler, W.A.; Elliott, T.S. Identification of a novel antigen from Staphylococcus epidermidis. FEMS Immunol. Med. Microbiol. 2000, 29, 213-220. [CrossRef]

80. Resch, A.; Rosenstein, R.; Nerz, C.; Götz, F. Differential gene expression profiling of Staphylococcus aureus cultivated under biofilm and planktonic conditions. Appl. Environ. Microbiol. 2005, 71, 2663-2676. [CrossRef]

81. Merino, N.; Toledo-Arana, A.; Vergara-Irigaray, M.; Valle, J.; Solano, C.; Calvo, E.; Lopez, J.A.; Foster, T.J.; Penadés, J.R.; Lasa, I. Protein A-mediated multicellular behavior in Staphylococcus aureus. J. Bacteriol. 2009, 191, 832-843. [CrossRef]

82. Chen, C.; Zabad, S.; Liu, H.; Wang, W.; Jeffery, C. MoonProt 2.0: An expansion and update of the moonlighting proteins database. Nucleic Acids Res. 2018, 46, D640-D644. [CrossRef] [PubMed]

83. Franco-Serrano, L.; Hernández, S.; Calvo, A.; Severi, M.A.; Ferragut, G.; Pérez-Pons, J.A.; Piñol, J.; Pich, Ò.; Mozo-Villarias, Á.; Amela, I.; et al. MultitaskProtDB-II: An update of a database of multitasking/moonlighting proteins. Nucleic Acids Res. 2018, 46, D645-D648. [CrossRef] [PubMed]

84. Ebner, P.; Rinker, J.; Götz, F. Excretion of cytoplasmic proteins in Staphylococcus is most likely not due to cell lysis. Curr. Genet. 2016, 62, 19-23. [CrossRef] [PubMed]

85. Rice, K.C.; Mann, E.E.; Endres, J.L.; Weiss, E.C.; Cassat, J.E.; Smeltzer, M.S.; Bayles, K.W. The cidA murein hydrolase regulator contributes to DNA release and biofilm development in Staphylococcus aureus. Proc. Natl. Acad. Sci. USA 2007, 104, 8113-8118. [CrossRef] [PubMed]

86. Mashruwala, A.A.; Guchte, A.V.; Boyd, J.M. Impaired respiration elicits SrrAB-dependent programmed cell lysis and biofilm formation in Staphylococcus aureus. eLife 2017, 6, e23845. [CrossRef] [PubMed] 
87. Pasztor, L.; Ziebandt, A.K.; Nega, M.; Schlag, M.; Haase, S.; Franz-Wachtel, M.; Madlung, J.; Nordheim, A.; Heinrichs, D.E.; Götz, F. Staphylococcal major autolysin (Atl) is involved in excretion of cytoplasmic proteins. J. Biol. Chem. 2010, 285, 36794-36803. [CrossRef] [PubMed]

88. Yang, C.K.; Zhang, X.Z.; Lu, C.D.; Tai, P.C. An internal hydrophobic helical domain of Bacillus subtilis enolase is essential but not sufficient as a non-cleavable signal for its secretion. Biochem. Biophys. Res. Commun. 2014, 446, 901-905. [CrossRef]

89. Widjaja, M.; Harvey, K.L.; Hagemann, L.; Berry, I.J.; Jarocki, V.M.; Raymond, B.B.A.; Tacchi, J.L.; Gründel, A.; Steele, J.R.; Padula, M.P.; et al. Elongation factor tu is a multifunctional and processed moonlighting protein. Sci. Rep. 2017, 7, 11227. [CrossRef]

90. Kainulainen, V.; Korhonen, T.K. Dancing to another tune-adhesive moonlighting proteins in bacteria. Biology 2014, 3, 178-204. [CrossRef]

91. Rieu, A.; Aoudia, N.; Jego, G.; Chluba, J.; Yousfi, N.; Briandet, R.; Deschamps, J.; Gasquet, B.; Monedero, V.; Garrido, C.; et al. The biofilm mode of life boosts the anti-inflammatory properties of Lactobacillus. Cell. Microbiol. 2014, 16, 1836-1853. [CrossRef]

92. Arita-Morioka, K.; Yamanaka, K.; Mizunoe, Y.; Ogura, T.; Sugimoto, S. Novel strategy for biofilm inhibition by using small molecules targeting molecular chaperone DnaK. Antimicrob. Agents Chemother. 2015, 59, 633-641. [CrossRef] [PubMed]

93. Vastano, V.; Pagano, A.; Fusco, A.; Merola, G.; Sacco, M.; Donnarumma, G. The Lactobacillus plantarum EnoA1 enolase is involved in immunostimulation of caco-2 cells and in biofilm development. Adv. Exp. Med. Biol. 2016, 897, 33-44. [CrossRef] [PubMed]

94. Daubenspeck, J.M.; Liu, R.; Dybvig, K. Rhamnose links moonlighting proteins to membrane phospholipid in Mycoplasmas. PLoS ONE 2016, 11, e0162505. [CrossRef] [PubMed]

95. Alreshidi, M.M.; Dunstan, R.H.; Gottfries, J.; Macdonald, M.M.; Crompton, M.J.; Ang, C.S.; Williamson, N.A.; Roberts, T.K. Changes in the cytoplasmic composition of amino acids and proteins observed in Staphylococcus aureus during growth under variable growth conditions representative of the human wound site. PLoS ONE 2016, 11, e0159662. [CrossRef]

96. Voigt, B.; Albrecht, D.; Dalhoff, A. Mode of action of MCB3681 in Staphylococcus aureus-A proteomic study. Arch. Clin. Microbiol. 2016, 7, 31. [CrossRef]

97. Richardson, A.R.; Somerville, G.A.; Sonenshein, A.L. Regulating the intersection of metabolism and pathogenesis in gram-positive bacteria. Microbiol. Spectr. 2015, 3. [CrossRef]

98. Lee, E.Y.; Choi, D.Y.; Kim, D.K.; Kim, J.W.; Park, J.O.; Kim, S.; Kim, S.H.; Desiderio, D.M.; Kim, Y.K.; Kim, K.P.; et al. Gram-Positive bacteria produce membrane vesicles: Proteomics-Based characterization of Staphylococcus aureus-derived membrane vesicles. Proteomics 2009, 9, 5425-5436. [CrossRef]

99. Lee, J.; Lee, E.Y.; Kim, S.H.; Kim, D.K.; Park, K.S.; Kim, K.P.; Kim, Y.K.; Roh, T.Y.; Gho, Y.S. Staphylococcus aureus extracellular vesicles carry biologically active $\beta$-lactamase. Antimicrob. Agents Chemother. 2013, 57, 2589-2595. [CrossRef]

100. Kulp, A.; Kuehn, M.J. Biological functions and biogenesis of secreted bacterial outer membrane vesicles. Annu. Rev. Microbiol. 2010, 64, 163-184. [CrossRef]

101. Gurung, M.; Moon, D.C.; Choi, C.W.; Lee, J.H.; Bae, Y.C.; Kim, J.; Lee, Y.C.; Seol, S.Y.; Cho, D.T.; Kim, S.I.; et al. Staphylococcus aureus produces membrane-derived vesicles that induce host cell death. PLoS ONE 2011, 6, e27958. [CrossRef]

102. Jeon, H.; Oh, M.H.; Jun, S.H.; Kim, S.I.; Choi, C.W.; Kwon, H.I.; Na, S.H.; Kim, Y.J.; Nicholas, A.; Selasi, G.N.; et al. Variation among Staphylococcus aureus membrane vesicle proteomes affects cytotoxicity of host cells. Microb. Pathog. 2016, 93, 185-193. [CrossRef] [PubMed]

103. Maidhof, H.; Reinicke, B.; Blümel, P.; Berger-Bächi, B.; Labischinski, H. FemA, which encodes a factor essential for expression of methicillin resistance, affects glycine content of peptidoglycan in methicillin-resistant and methicillin-susceptible Staphylococcus aureus strains. J. Bacteriol. 1991, 173, 3507-3513. [CrossRef] [PubMed]

104. Henze, U.; Sidow, T.; Wecke, J.; Labischinski, H.; Berger-Bächi, B. Influence of femB on methicillin resistance and peptidoglycan metabolism in Staphylococcus aureus. J Bacteriol. 1993, 175, 1612-1620. [CrossRef] [PubMed]

105. Rahman, M.M.; Hunter, H.N.; Prova, S.; Verma, V.; Qamar, A.; Golemi-Kotra, D. The Staphylococcus aureus methicillin resistance factor FmtA is a D-amino esterase that acts on teichoic acids. mBio 2016, 7, e02070-15. [CrossRef] [PubMed] 
106. Courvalin, P. Vancomycin resistance in gram-positive cocci. Clin. Infect. Dis. 2006, 42, S25-S34. [CrossRef]

107. Mirelman, D.; Sharon, N. Biosynthesis of peptidoglycan by a cell wall preparation of Staphylococcus aureus and its inhibition by penicillin. Biochem. Biophys. Res. Commun. 1972, 46, 1909-1917. [CrossRef]

108. Valentín, S.; Morales, A.; Sánchez, J.L.; Rivera, A. Safety and efficacy of doxycycline in the treatment of rosacea. Clin. Cosmet. Investig. Dermatol. 2009, 2, 129-140. [CrossRef]

109. Hooper, D.C. Mode of action of fluoroquinolones. Drugs 1999, 58, 6-10. [CrossRef]

110. Li, C.; Renz, N.; Trampuz, A. Management of periprosthetic joint infection. Hip Pelvis 2018, 30, $138-146$. [CrossRef]

111. Manner, S.; Goeres, D.M.; Skogman, M.; Vuorela, P.; Fallarero, A. Prevention of Staphylococcus aureus biofilm formation by antibiotics in 96-microtiter well plates and drip flow reactors: Critical factors influencing outcomes. Sci. Rep. 2017, 7, 43854. [CrossRef]

112. Mandell, J.B.; Orr, S.; Koch, J.; Nourie, B.; Ma, D.; Bonar, D.D.; Shah, N.; Urish, K.L. Large variations in clinical antibiotic activity against Staphylococcus aureus biofilms of periprosthetic joint infection isolates. J. Orthop. Res. 2019, 37, 1604-1609. [CrossRef] [PubMed]

113. Michalik, S.; Depke, M.; Murr, A.; Gesell Salazar, M.; Kusebauch, U.; Sun, Z.; Meyer, T.C.; Surmann, K.; Pförtner, H.; Hildebrandt, P.; et al. A global Staphylococcus aureus proteome resource applied to the in vivo characterization of host-pathogen interactions. Sci. Rep. 2017, 7, 9718. [CrossRef] [PubMed]

114. Frees, D.; Chastanet, A.; Qazi, S.; Sørensen, K.; Hill, P.; Msadek, T.; Ingmer, H. Clp ATPases are required for stress tolerance, intracellular replication and biofilm formation in Staphylococcus aureus. Mol. Microbiol. 2004, 54, 1445-1462. [CrossRef] [PubMed]

115. Conlon, B.P.; Nakayasu, E.S.; Fleck, L.E.; LaFleur, M.D.; Isabella, V.M.; Coleman, K.; Leonard, S.N.; Smith, R.D.; Adkins, J.N.; Lewis, K. Activated ClpP kills persisters and eradicates a chronic biofilm infection. Nature 2013, 503, 365-370. [CrossRef] [PubMed]

(C) 2019 by the authors. Licensee MDPI, Basel, Switzerland. This article is an open access article distributed under the terms and conditions of the Creative Commons Attribution (CC BY) license (http://creativecommons.org/licenses/by/4.0/). 